\title{
Petrology, geochemistry, and U-Pb (zircon) age of the quartz-feldspar porphyry dyke at the Lake George antimony mine, New Brunswick: implications for origin, emplacement process, and mineralization
}

\author{
P.R.R. LEONARD ${ }^{1}$, D.R. Lentz ${ }^{1 *}$, AND M. POUJOL ${ }^{2}$ \\ 1. Department of Geology, University of New Brunswick, P. O. Box 4400, Fredericton, New Brunswick, Canada E3B 5A3 \\ 2. Department of Earth Sciences, Memorial University of Newfoundland, St. John's, NL, Canada, A1B 3X5 \\ *Corresponding author:<dlentz@unb.ca>
}

Date received: 20 April 2005 Date accepted: 27 July 2005

\begin{abstract}
A steeply west-dipping, north-northwest-trending, biotite-bearing quartz-feldspar porphyry dyke is associated with the Lake George granodiorite, a cupola of the Pokiok Batholith. These Early Devonian intrusions are spatially and temporally related to W-Mo-Au and Sb-Au mineralization in the area. The porphyry dyke yielded an age of 420.8 $+5.9 /-4.0 \mathrm{Ma}$ (U-Pb zircon) and is inferred to be coeval with or slightly older than the Lake George granodiorite (412 $+5 /-4 \mathrm{Ma}, \mathrm{U}-\mathrm{Pb}$ zircon). The variably altered dyke contains subhedral to anhedral (rounded) quartz, plagioclase, and orthoclase phenocrysts ( 0.5 to $30 \mathrm{~mm} ; 30$ to 60 vol. \%), and numerous angular to subrounded xenoliths of altered intrusion carapace and quenched dyke rocks, as well as local Kingsclear Formation metasedimentary rocks. The dyke is similar to the Lake George granodiorite in phenocryst population, volcanic arc (I-type) affinity, average $\mathrm{Zr}$ (157 $\mathrm{ppm}), \mathrm{TiO}_{2}(0.54 \%), \mathrm{La} / \mathrm{Yb}$ ratio (13), and $\mathrm{REE}(129 \mathrm{ppm})$. The average Au content is lower in the dyke (20 ppb) than in the granodiorite (32 ppb), the abundance of gold is related to minor magmatic hydrothermal chalcopyrite and pyrrhotite $(<2 \%)$. Based on textural evidence, including autobrecciation, coupled with rheological and thermal modeling calculations for the $5 \mathrm{~m}$-wide dyke, it is suggested that fluidization (vapour exsolution) of the magma was key to its rapid emplacement as a quenched glass-gas mixture (tuffisite). The $S$ abundance and $S$ isotopic signature of the dyke, relative to $\mathrm{Au}$ and $\mathrm{Cu}$ abundance, support reduced I-type magmatic volatiles involved in dyke emplacement and cogenetic autometasomatic alteration.
\end{abstract}

\section{RÉSUMÉ}

Un dyke de porphyre quartzo-feldspathique renfermant de la biotite, orienté vers le nord-nord-ouest et s'inclinant abruptement vers l'ouest, est associé à la granodiorite du lac George, une coupole du magmatisme du batholite de Pokiok. Ces intrusions régionales du Dévonien précoce sont spatialement et temporellement apparentées à une minéralisation de W-Mo-Au et de Sb-Au dans le secteur. Le dyke de porphyre a accusé un âge de 420,8 +5,9/-4,0 Ma (U-Pb sur zircon) et on le suppose du même âge ou légèrement plus âgé que la granodiorite du lac George ( $412+5 /-4 \mathrm{Ma}$, U-Pb sur zircon). Le dyke altéré de façon variable abrite des phénocristaux hypautomorphes à allotriomorphes (arrondis) de quartz, de plagioclase et d'orthoclase $(0,5$ à $30 \mathrm{~mm}, 30$ à $60 \%$ en vol.) ainsi que de nombreux xénolites angulaires à subsphérique d'une carapace d'intrusion altérée et de roches de dykes noyées, en plus de roches métasédimentaires locales de la Formation de Kingsclear. Le dyke s'avère analogue à la granodiorite du lac George du point de vue de la population de phénocristaux, de l'affinité avec l'arc insulaire (de type intrusif), de la concentration moyenne de $\mathrm{Zr}$ (157 ppm), du TiO 2 (0,54 \%), du ratio de La/Yb (13) et des ÉTR (129 ppm). La teneur moyenne en Au est plus faible dans le dyke (20 parties par milliard) que dans la granodiorite (32 parties par milliard); son abondance est apparentée à la présence restreinte de chalcopyrite et de pyrrhotite hydrothermales magmatiques $(<2 \%)$. Selon les indices texturaux, notamment l'autobréchification, conjugués à des calculs de modélisation rhéologique et thermale du dyke $(5 \mathrm{~m})$, on peut supposer que la fluidisation (exsolution à l'état de vapeur) du magma a contribué à sa mise en place rapide sous forme d'un mélange de verre-gaz (tuffisite) noyé. L'abondance de $S$ et la signature isotopique du S du dyke, comparativement à l'abondance d'Au et de $\mathrm{Cu}$, appuient la participation réduite d'éléments volatils magmatiques de type intrusif à la mise en place du dyke et à l'altération autométasomatique cogénétique.

[Traduit par la rédaction] 


\section{INTRODUCTION}

The Lake George mine is located approximately $40 \mathrm{~km}$ west of Fredericton, New Brunswick (Fig. 1a) and was formerly the largest producer of antimony in North America. Interest in the area has recently been revived with the discovery of gold anomalies in drill cores (Morrissy 1991; Lentz et al. 2002a). These anomalies are thought to be associated with the nearby Lake George granodiorite stock (Seal et al. 1988), which is situated $500 \mathrm{~m}$ northwest of the Hibbard Shaft and $350 \mathrm{~m}$ below surface. A strongly fractured contact aureole around the stock likely provided conduits for mineralizing fluids bearing $\mathrm{Sb}, \mathrm{W}$, $\mathrm{Mo}, \mathrm{Au}$, and base metals. Tightly folded calcareous turbiditic rocks, metamorphosed to greenschist facies (Seal et al. 1987, 1988; Caron 1996) of the Silurian Kingsclear Group form the country rock around the Lake George granodiorite, which lies approximately $350 \mathrm{~m}$ below the surface along the southeastern margin of the Pokiok Batholith. A contact aureole surrounding the intrusion is indicated by the presence of biotite and cordierite porphyroblasts in the pelitic rocks (Seal et al. 1987; 1988; Caron 1996).

Prior to the intrusion of the granodiorite stock, steeply dipping east-trending lamprophyre dykes were discordantly emplaced into the Silurian Kingsclear Group. The focus of the present study is a northwest-trending quartz-feldspar porphyry (QFP) dyke which also intrudes the metasedimentary rocks, although its relationship to the granodioritic stock is uncertian (Morrissy and Ruitenberg 1980; Lentz et al. 2002b). The QFP dyke has a north-northwest orientation (Procyshyn and Morrissy 1990), dips steeply to the west $\left(80^{\circ}\right)$, and is 3 to $5 \mathrm{~m}$ wide (Seal et al. 1988). The dyke bifurcates with a separation of less than $25 \mathrm{~m}$ between the branches, which merge along strike and at depth. The QFP dyke crosscuts narrow east-west lamprophyre dykes (Lentz et al. 2002b) but is inferred to be intruded by the Lake George quartz-hornblende-plagioclasephyric granodiorite stock at depth (Fig. 1).

The Pokiok Batholith (Fig. 1a) has been subdivided into five units (Ruitenberg and Fyffe 1982; Lutes 1987; Whalen 1993, Whalen et al. 1996). The Hartfield tonalite is the oldest unit (U-Pb titanite, $415 \pm 1 \mathrm{Ma}$ ), followed by the Skiff Lake granite (U-Pb zircon, $409 \pm 2 \mathrm{Ma}$ ) and the Hawkshaw granite (U-Pb titanite, $411 \pm 1 \mathrm{Ma}$ ) (Bevier and Whalen 1990a, b; Whalen 1993). The Lake George granodiorite stock (U-Pb zircon 412 +5/-4 Ma; McLeod et al. 2003) is chemically and petrologically similar to the Hawkshaw granite of the Pokiok Batholith, although there are some mineralogical differences (Yang et al. $2002 \mathrm{a}, \mathrm{b})$. The Allandale granite is the youngest unit (U-Pb monazite, $402 \pm 1 \mathrm{Ma}$ ) of the Pokiok Batholith. It is possible that the Hartfield, Skiff Lake, and Hawkshaw units represent a sequential fractionation and emplacement series, although the age of the Allandale granite is too young to be related to the main intrusive episodes of the batholith.

The purpose of this study is to examine the QFP dyke in the area and to determine its relationship to the magmatic activity in the region and timing relative to the two episodes of mineralization(W-Mo-Au and $\mathrm{Sb}-\mathrm{Au}$ ). Previous reports suggested that the dyke predates the granodioritic intrusion (Morrissy and Ruitenberg 1980), which is consistent with it being locally crosscut and altered by both the Hibbard $\mathrm{Sb}$ vein and the intrusion-related gold-bearing quartz-scheelite-molybdenite veinlets (Seal et al. 1988), although crosscutting relationships between the dyke and the stock were not observed in this study. As the granodiorite stock is linked to the exocontact W-Mo-Au mineralization (Lentz et al. 2002a), information on the QFP dyke could enhance exploration efforts for $\mathrm{Au}$ (W-Mo) in the area, because (1) it could indicate the presence of larger granodiorite intrusions at depth and of magmatic systems of similar petrologic association, (2) intrinsic metal abundances may reveal the presence of a favourable magmatic hydrothermal system, and (3) aspects related to dyke emplacement indirectly provide evidence of the role of volatiles in emplacement that indirectly controls the distribution of exocontact Au-W-Mo mineralization in the region.

\section{DYKE PETROLOGY}

The rock-forming minerals in the QFP dyke at Lake George were first examined in polished drill-hole cores samples (Fig. 2) to observe variations in texture and mineralogy. [NoTE: Sample numbers indicate diamond drill hole number and depth. For simplicity, the $\mathrm{m}$ (for metres) is omitted from each sample number.] The metasedimentary host rocks in contact with the dyke have preserved no macroscopic evidence of contact hornfelsing associated with dyke emplacement. Samples from the host rocks contain 30 to $60 \%$ anhedral quartz and subhedral and anhedral feldspar phenocrysts ranging from 5 to $12 \mathrm{~mm}$ in length (Fig. 2a). The dyke mineralogy generally consists of porphyritic and fine-grained quartz, plagioclase, and orthoclase with accessory biotite ( $<2 \mathrm{~mm}$ in length), chlorite, muscovite, pyrite, pyrrhotite $(<3 \%)$, chalcopyrite, calcite, titanite, and rutile. Ilmenite, zircon, monazite, and apatite are present but recognizable only at the sub-microscopic scale through SEM-EDS analysis. The samples differ in their degree of sericitization. Based on observed abundance of sericite and chlorite, sample DDH 81-25-19.2 is the least altered and sample DDH 79-6-195.5 is most altered. Sample DDH 81-21-181.1 (Fig. 2b) has a prominent fracture running the length of the core with strong sericitization. Sample DDH 81-26-63.4 (Fig. $2 c$ ) is interesting in that it contains a fragment that has a dark homogeneous microcrystalline matrix, morphologically and compositionally unlike the sedimentary host rocks (see Scratch et al. 1984). Sample DDH 79-6-210 has dark rounded xenoliths up to $10 \mathrm{~mm}$ in size (10 to 15 percent) (Fig. $2 \mathrm{~d}$ ) (see also DDH 81-26-63.4). These xenoliths resemble autobrecciated altered intrusive rocks, consistent with their similar compositions (see below).

Rounded quartz occurs generally in two size populations (see Fig. 3a); phenocrysts and phenoclasts (ave $0.7 \mathrm{~mm}$ ) with a groundmass consisting of grains $<0.1 \mathrm{~mm}$ in size. They measure up to $6 \mathrm{~mm}$, although the average is about $0.7 \mathrm{~mm}$. The larger grains commonly contain melt inclusions and secondary 

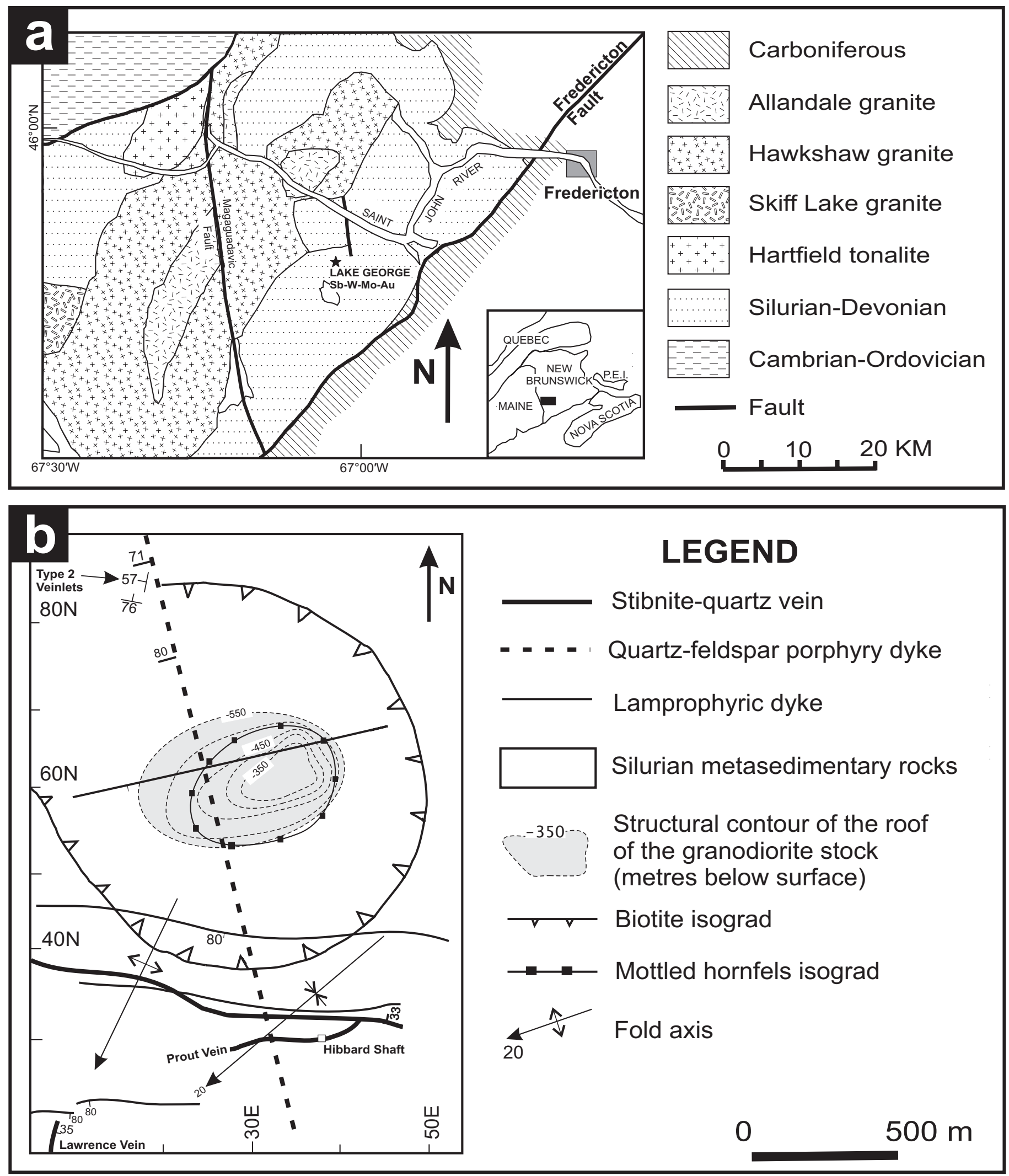

Fig. 1 (a) General geology of the Pokiok Batholith and surrounding area near the Lake George antimony mine, New Brunswick. (b) Map showing the subsurface Lake George granodiorite stock in relation to the QFP dyke (modified after Seal et al. 1988 and Lentz et al. 2002a). 

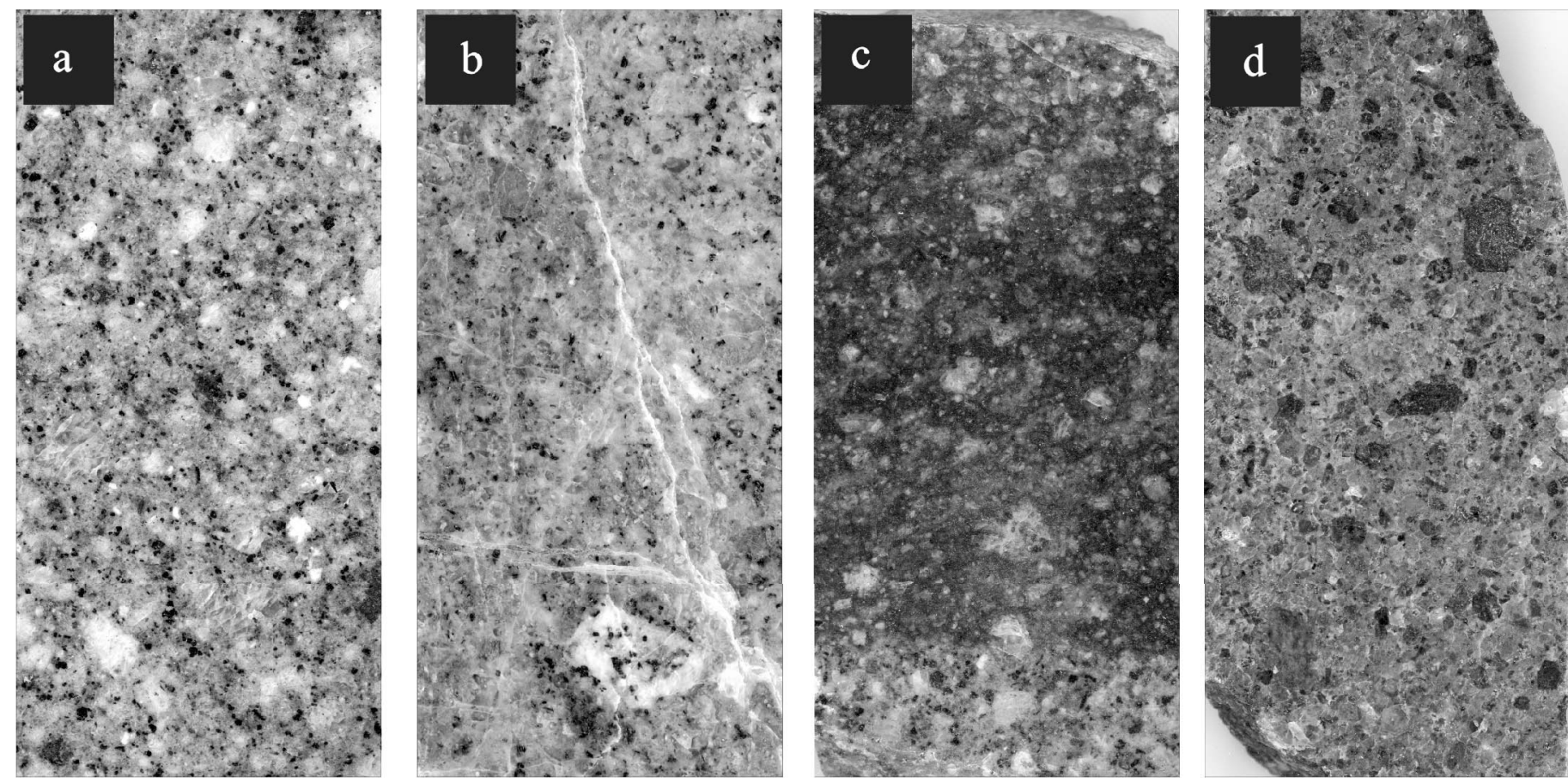

Fig. 2 Slab photographs of QFP dyke at Lake George: (a) sample DDH 81-25-19.2 contains quartz and feldspar phenocrysts; (b) sericitic alteration in proximity to the fracture in DDH 81-21-594 as the result of feldspar alteration. Sericitization was facilitated by the fracture that behaved as a conduit for fluid transportation; (c) sample DDH 81-26-62.8 contains a fragment with a dark matrix with intense graphic texture; (d) black xenoliths in DDH 79-6-210 are unique to this sample and are intensely sericitized feldspar.
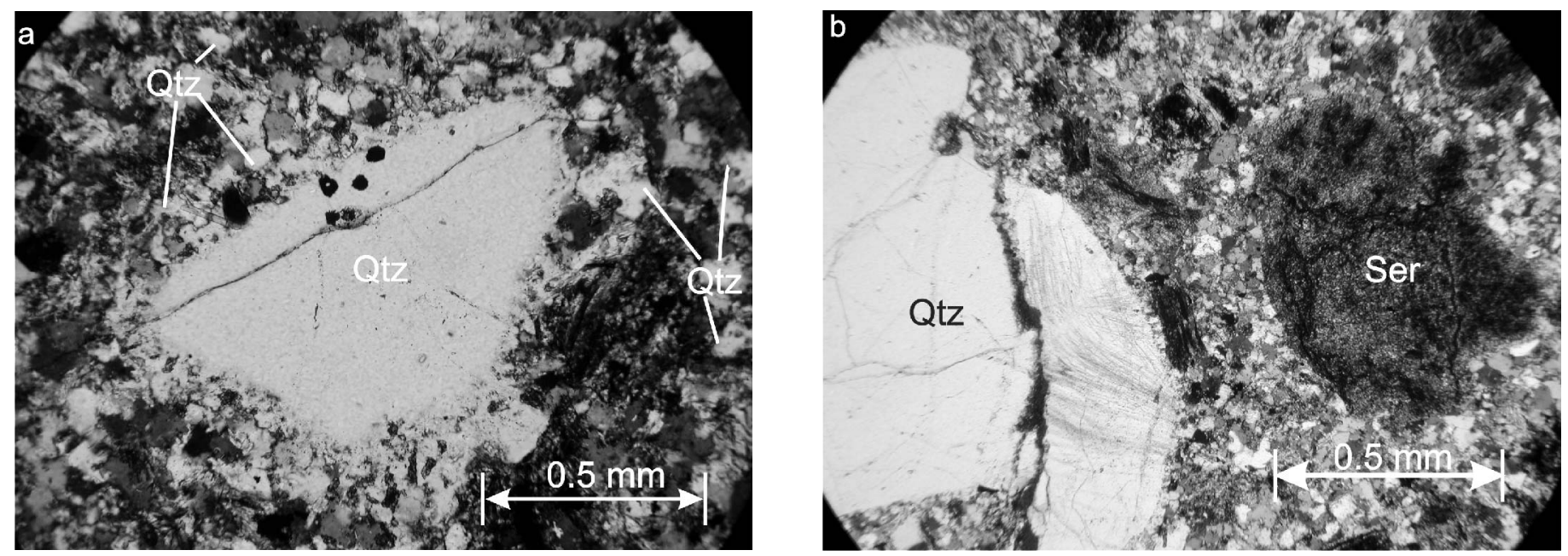

Fig. 3 Photomicrographs showing two populations of quartz from sample DDH 79-6-210 in crossed polarized light (CPL). (a) larger subhedral quartz phenoclast in contact with smaller more numerous quartz grains. (b) large quartz phenocryst (on the left) with melt and fluid inclusions from sample DDH 79-6-210 (CPL) shows where the surrounding melt was trapped by the growing quartz along the grain boundary. The low birefringence bleb (on the right) represents the remnant of plagioclase phenocrysts pseudomorphed by sericitization. 
fluid inclusions, and appear to have been a nucleation point for crystal growth (see Fig. 3b).

Feldspars are present in high proportions in every sample, but typically have undergone extensive alteration to sericite. Plagioclase crystals show various degrees of sericitization, but some display relict zoning and twinning (Fig. 4; Table 1). The zoning in most of the plagioclase crystals is irregular and the edges of some grains are rounded, which is evidence for periods of both crystal growth and resorption, and (or) possible abrasion. Plagioclase has inclusions of potassium feldspar, apatite, zircon, chlorite, Fe sulphides, and rutile. Granophyric (more wormy) to graphic (more cuneiform) intergrowths between feldspar and quartz are evident in three samples (DDH 79-6174.3, DDH 81-26-63.4, and DDH83-1-37.5; Fig. 5). Chlorite appears to be a local alteration product of reddish-brown biotite (Fig. 6). Primary biotite crystals $\left(4.4\right.$ wt. $\% \mathrm{TiO}_{2}$ by SEM-EDS analysis) contain inclusions of zircon, apatite, pyrite, albite, interlayered muscovite, and locally trellis-like rutile needles.

Sample magnetic susceptibility ranges from 1.1 to $13.5 \times$ $10^{-4}$ (S.I. units) (see Table 2), typical of transitional reduced to oxidized magnetite-type magma (see Ishihara 1981), although most samples contain magnetic pyrrhotite rather than magnetite. Pyrrhotite and chalcopyrite are present in most samples, although probably a high temperature alteration feature, as

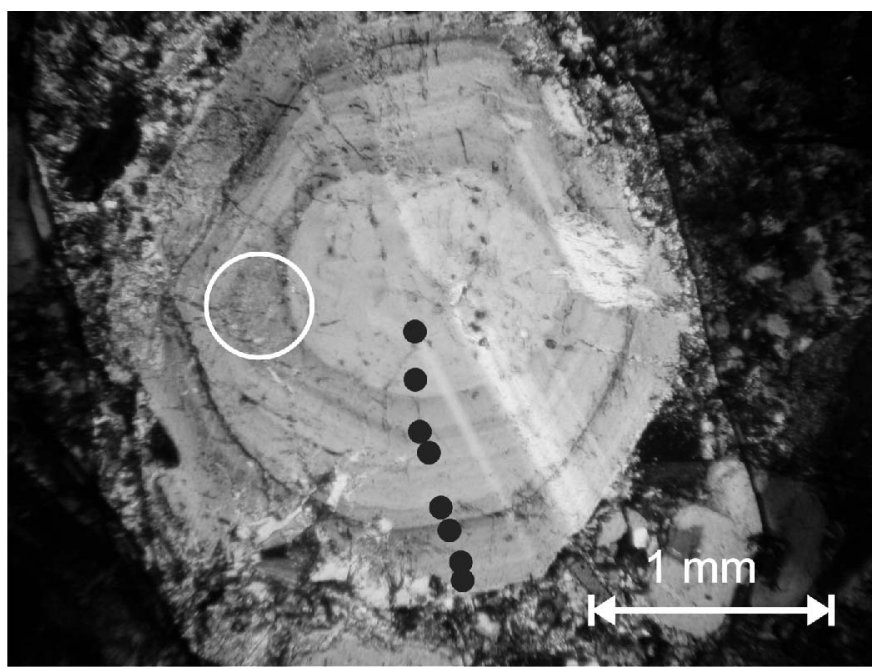

Fig. 4 Photomicrograph of complexly zoned plagioclase phenocrysts (CPL) in sample DDH 83-1-37.5 with variable degrees of sericitization (circled), and also showing signs of resorbtion in the irregular zoning. SEM-EDS analyses across the plagioclase are marked by black dots; the data are presented in Table 1.

Table 1. SEM-EDS analyses of transects of zoned plagioclase grains from the QFP dyke at the Lake George mine

\begin{tabular}{|c|c|c|c|c|c|c|c|c|c|c|c|}
\hline & $\mathrm{SiO}_{2}$ & $\mathrm{Al}_{2} \mathrm{O}_{3}$ & $\mathrm{CaO}$ & $\mathrm{Na}_{2} \mathrm{O}$ & $\mathrm{K}_{2} \mathrm{O}$ & $\mathrm{MgO}$ & $\mathrm{FeO}$ & Total & $\mathrm{Ab}$ & An & Or \\
\hline \multicolumn{12}{|c|}{ Sample DDH 81-26-63.4 } \\
\hline \multirow[t]{7}{*}{ core } & 61.05 & 24.15 & 5.74 & 7.98 & 0.61 & 0.14 & 0.08 & 99.75 & 0.542 & 0.431 & 0.027 \\
\hline & 61.23 & 23.92 & 5.34 & 7.97 & 0.80 & 0.12 & 0.10 & 99.48 & 0.554 & 0.410 & 0.037 \\
\hline & 59.49 & 24.77 & 6.39 & 7.61 & 0.74 & 0.13 & 0.21 & 99.34 & 0.502 & 0.466 & 0.032 \\
\hline & 60.19 & 24.71 & 6.18 & 7.74 & 0.64 & 0.21 & 0.05 & 99.72 & 0.516 & 0.456 & 0.028 \\
\hline & 60.12 & 24.81 & 6.40 & 7.61 & 0.65 & 0.16 & 0.17 & 99.92 & 0.504 & 0.468 & 0.028 \\
\hline & 58.32 & 25.48 & 7.32 & 6.93 & 0.47 & 0.12 & 0.21 & 98.85 & 0.452 & 0.528 & 0.020 \\
\hline & 60.27 & 24.29 & 5.89 & 7.62 & 0.78 & 0.09 & 0.00 & 98.94 & 0.520 & 0.445 & 0.035 \\
\hline rim & 59.77 & 24.97 & 6.57 & 7.46 & 0.58 & 0.15 & 0.20 & 99.70 & 0.494 & 0.481 & 0.025 \\
\hline \multicolumn{12}{|c|}{ Sample DDH 83-1-37.5 } \\
\hline \multirow[t]{7}{*}{ core } & 60.99 & 25.07 & 6.18 & 7.50 & 0.67 & 0.27 & 0.18 & 100.86 & 0.508 & 0.462 & 0.030 \\
\hline & 61.16 & 25.03 & 6.37 & 7.48 & 0.70 & 0.28 & 0.14 & 101.16 & 0.499 & 0.470 & 0.031 \\
\hline & 59.76 & 25.52 & 6.85 & 7.04 & 0.63 & 0.27 & 0.10 & 100.17 & 0.469 & 0.504 & 0.028 \\
\hline & 58.99 & 24.79 & 6.55 & 7.25 & 0.67 & 0.28 & 0.00 & 98.53 & 0.486 & 0.485 & 0.030 \\
\hline & 60.27 & 25.83 & 6.96 & 7.19 & 0.67 & 0.25 & 0.24 & 101.41 & 0.469 & 0.502 & 0.029 \\
\hline & 58.48 & 26.81 & 8.19 & 6.58 & 0.49 & 0.30 & 0.15 & 101.00 & 0.412 & 0.567 & 0.020 \\
\hline & 60.71 & 24.99 & 6.42 & 7.48 & 0.65 & 0.20 & 0.07 & 100.52 & 0.499 & 0.473 & 0.029 \\
\hline rim & 61.29 & 24.96 & 6.33 & 7.79 & 0.60 & 0.31 & 0.12 & 101.40 & 0.513 & 0.461 & 0.026 \\
\hline \multicolumn{12}{|c|}{ Sample DDH 83-1-37.5 } \\
\hline \multirow[t]{4}{*}{ core } & 61.43 & 24.86 & 5.98 & 7.58 & 0.65 & 0.28 & 0.16 & 100.94 & 0.519 & 0.452 & 0.029 \\
\hline & 60.41 & 25.56 & 6.80 & 6.96 & 0.66 & 0.24 & 0.00 & 100.63 & 0.467 & 0.504 & 0.029 \\
\hline & 61.06 & 24.98 & 6.15 & 7.56 & 0.59 & 0.23 & 0.00 & 100.57 & 0.513 & 0.461 & 0.026 \\
\hline & 59.21 & 25.59 & 7.21 & 6.97 & 0.58 & 0.23 & 0.14 & 99.93 & 0.455 & 0.520 & 0.025 \\
\hline rim & 61.08 & 24.63 & 5.86 & 7.80 & 0.51 & 0.25 & 0.08 & 100.21 & 0.534 & 0.443 & 0.023 \\
\hline
\end{tabular}



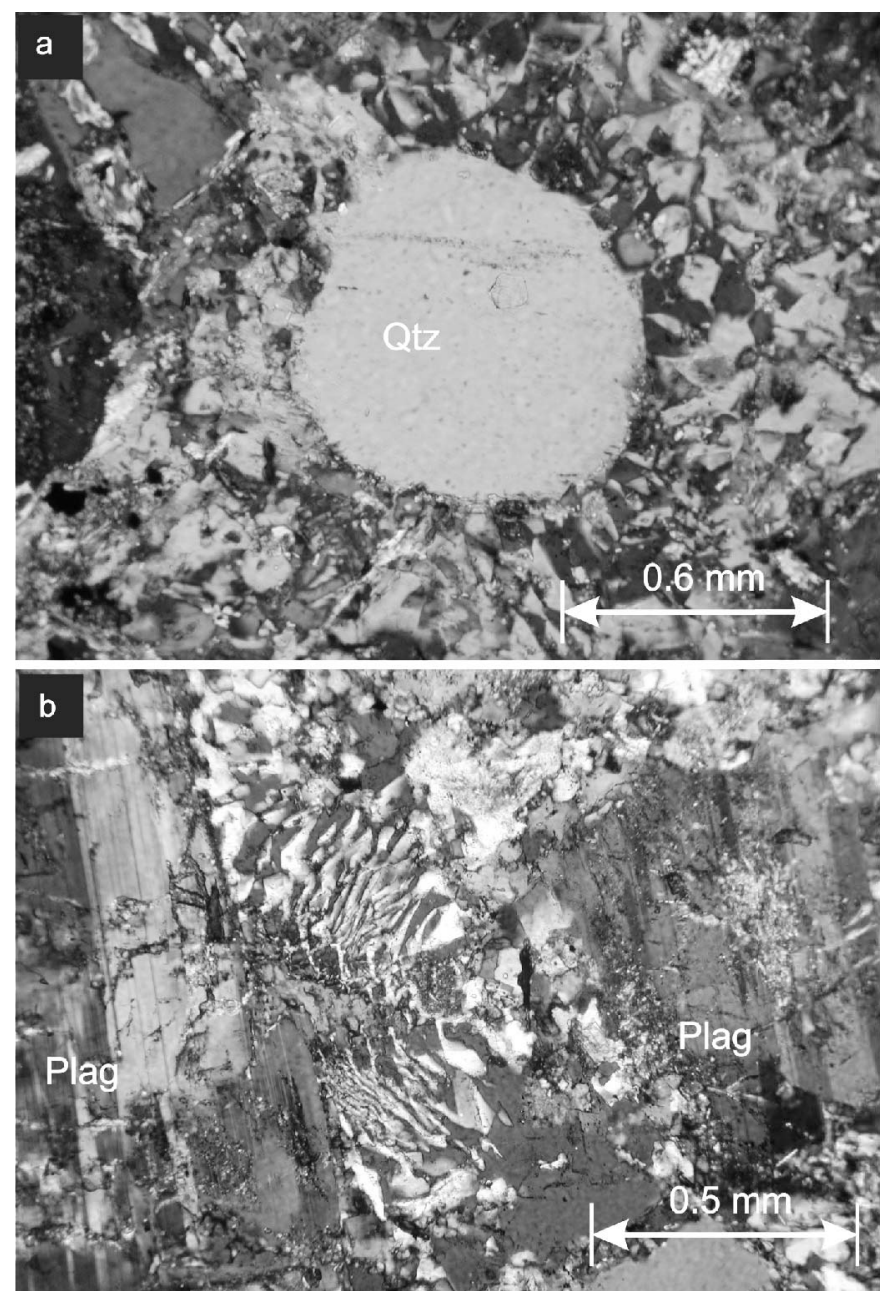

Fig. 5 Photomicrographs of graphic to granophyric intergrowth texture between quartz and plagioclase in sample DDH 81-26-63.4. (a) Granophyric texture surrounding a quartz phenocryst (CPL). (b) Graphic texture between two plagioclase phenocrysts (CPL).

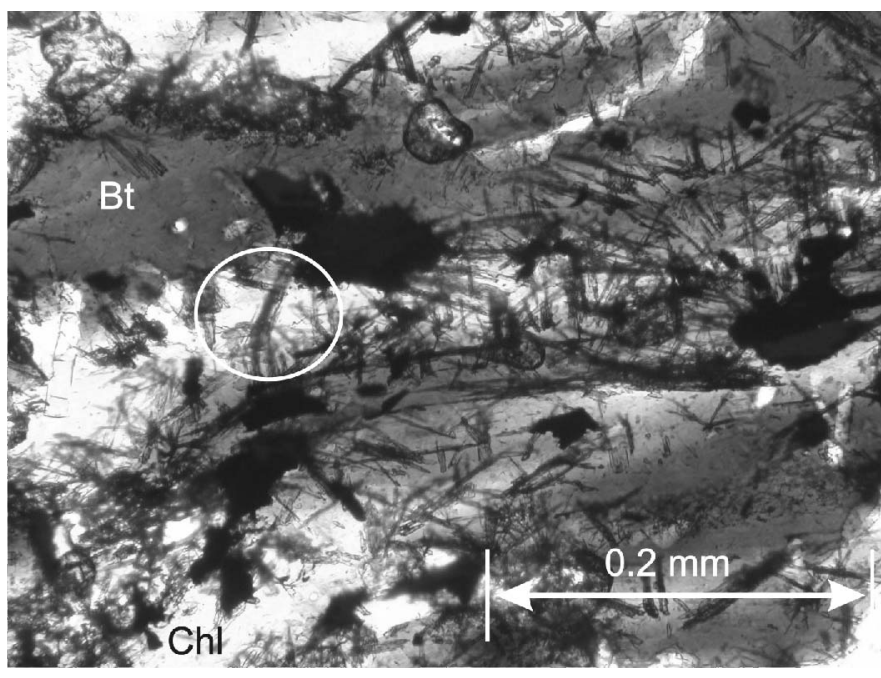

Fig. 6 Photomicrograph of biotite in sample DDH 79-6-195 in plane polarized light that are partially altered to chlorite. The needle-like grains (circled) are rutile. they coexist with alteration assemblages (as discussed later) and with biotite phenocrysts.

Euhedral titanite occurs as crystals less than $0.5 \mathrm{~mm}$ across, consistent with a relatively oxidized igneous system, although inconsistent with the reduced nature of the Lake George granodiorite. Apatite measures less than $0.1 \mathrm{~mm}$ in length and zircon is typically usually less than 100 microns, both as inclusions in biotite and plagioclase. As zircon and apatite apparently began to crystallize early, they may not be reliable thermometric indicators of dyke emplacement, but rather of maximum magma temperatures (Harrison and Watson 1984; Hanchar and Watson 2004).

Chlorite is present along fractures associated with calcite and, in some instances, contains intergrown bands of calcite. Narrow calcite veins (less than $0.2 \mathrm{~mm}$ wide) occupy microfractures, suggesting late paragenesis. Individual calcite grains contain pyrite inclusions. Some also contain minor pyrrhotite $(<2 \%)$ and chalcopyrite, typically tens of microns to $0.3 \mathrm{~mm}$ in size. Muscovite is commonly interstitial to larger plagioclase grains replacing K-feldspar phenocrysts; muscovite rosettes are common in altered parts of the dyke.

\section{GEOCHRONOLOGY}

Five single or double zircon fractions were analyzed (Table 3). On a concordia diagram (Fig. 7), they plot in a sub-concordant position (94 to $99.4 \%$ concordant) with the exception of grains $\mathrm{Zr} 3$, which are only $74 \%$ concordant with an apparent ${ }^{207} \mathrm{~Pb} /{ }^{206} \mathrm{~Pb}$ date of $757 \mathrm{Ma}$ (see Table 3). The four remaining grains define a well-constrained upper intercept date of 420.8 $+5.9 /-4.0 \mathrm{Ma}(\mathrm{MSWD}=2.9)$ with a lower intercept date of 59 $+85 /-87 \mathrm{Ma}$. The date of $421 \mathrm{Ma}$ is considered to be the age of intrusion of the QFP dyke. This age is older than the Lake George granodioritic stock (412+5/-4 Ma; McLeod et al. 2003), although the ages are the same within error. The apparent date of $757 \mathrm{Ma}$ from the $\mathrm{Zr} 3$ grains may be attributed to the presence of xenocrystic zircon incorporated from the country rock during dyke emplacement.

\section{GEOCHEMISTRY}

Whole-rock major-, trace-, and rare-earth-element (REEs) analyses of the QFP dyke are presented in Table 2. The Lake George granodiorite and dyke fall just within the low $\mathrm{SiO}_{2}$ suite of Devonian intrusions described by Whalen et al. (1996). ACNK [molar $\left.\mathrm{Al}_{2} \mathrm{O}_{3} /\left(\mathrm{CaO}+\mathrm{K}_{2} \mathrm{O}+\mathrm{Na}_{2} \mathrm{O}\right)\right]$ averages 1.09 for the least-altered samples. Normative mineralogy calculated from the whole-rock analysis and plotted on a QAP diagram (LeMaitre et al. 1989) places seven of the ten samples in the granodiorite field, and two in the granite field. The normative average of these nine samples is quartz $32.3 \%$, corundum $2.66 \%$, orthoclase $18.95 \%$, albite $22.32 \%$, anorthite $12.2 \%$, hypersthene $7.06 \%$, magnetite $1.38 \%$, ilmenite $1.03 \%$, and apatite $0.28 \%$. The tenth sample, DDH 79-6-210, is unusual in 
Table 2. Major-, minor- and trace-element analyses of the QFP dyke at the Lake George mine.

\begin{tabular}{|c|c|c|c|c|c|c|c|c|c|c|c|c|}
\hline $\begin{array}{l}\text { Sample } \\
\text { ID } \\
\text { 04-PL-\# }\end{array}$ & $\begin{array}{c}79-6- \\
195.5 \\
1\end{array}$ & $\begin{array}{c}79-6- \\
174.3 \\
2\end{array}$ & $\begin{array}{c}79-6- \\
210 \\
3\end{array}$ & $\begin{array}{c}81-4- \\
271.9 \\
4\end{array}$ & $\begin{array}{c}81-21- \\
181.1 \\
5\end{array}$ & $\begin{array}{c}81-21- \\
317.6 \\
6\end{array}$ & $\begin{array}{c}81-25- \\
19.2 \\
7\end{array}$ & $\begin{array}{c}81-26- \\
63.4 \\
8\end{array}$ & $\begin{array}{c}83-1- \\
37.5 \\
9\end{array}$ & $\begin{array}{c}81-14- \\
392.0 \\
10\end{array}$ & Average & SD \\
\hline \multicolumn{13}{|c|}{ Major and minor elements and L.O.I. ${ }^{1,2}$} \\
\hline $\mathrm{SiO}_{2}$ * & 66.7 & 69.6 & 71.6 & 70.3 & 68.4 & 68.1 & 68.0 & 69.8 & 67.2 & 68.6 & 68.83 & 1.49 \\
\hline $\mathrm{TiO}_{2}$ & 0.58 & 0.56 & 0.58 & 0.42 & 0.55 & 0.62 & 0.56 & 0.40 & 0.58 & 0.57 & 0.54 & 0.07 \\
\hline $\mathrm{Al}_{2} \mathrm{O}_{3}$ & 15.21 & 14.66 & 15.00 & 14.04 & 15.00 & 14.95 & 15.36 & 14.76 & 14.92 & 15.60 & 14.95 & 0.42 \\
\hline $\mathrm{Fe}_{2} \mathrm{O}_{3}{ }^{\mathrm{T}}$ & 4.25 & 3.60 & 6.40 & 3.32 & 3.48 & 4.15 & 4.19 & 3.17 & 4.35 & 4.12 & 4.10 & 0.91 \\
\hline $\mathrm{MnO}$ & 0.05 & 0.06 & 0.02 & 0.05 & 0.06 & 0.06 & 0.08 & 0.06 & 0.07 & 0.06 & 0.06 & 0.02 \\
\hline $\mathrm{MgO}$ & 1.47 & 0.99 & 1.46 & 0.71 & 0.95 & 1.19 & 1.39 & 0.84 & 1.37 & 1.42 & 1.18 & 0.28 \\
\hline $\mathrm{CaO}$ & 3.10 & 2.30 & 0.34 & 2.65 & 3.51 & 3.75 & 2.95 & 2.16 & 2.83 & 2.68 & 2.63 & 0.94 \\
\hline $\mathrm{Na}_{2} \mathrm{O}$ & 2.93 & 2.39 & 0.00 & 2.67 & 2.88 & 3.01 & 3.41 & 3.20 & 3.17 & 2.85 & 2.65 & 0.97 \\
\hline $\mathrm{K}_{2} \mathrm{O}$ & 3.01 & 3.66 & 3.03 & 3.76 & 3.37 & 2.52 & 2.96 & 3.73 & 3.33 & 2.77 & 3.21 & 0.42 \\
\hline $\mathrm{P}_{2} \mathrm{O}_{5}$ & 0.14 & 0.14 & 0.15 & 0.09 & 0.13 & 0.12 & 0.13 & 0.13 & 0.13 & 0.11 & 0.13 & 0.02 \\
\hline L.O.I. $^{2}$ & 3.55 & 3.28 & 3.86 & 3.02 & 3.84 & 4.38 & 1.38 & 1.09 & 2.13 & 3.89 & 3.04 & \\
\hline Total & $\overline{101.0}$ & $\overline{101.2}$ & $\overline{102.4}$ & $\overline{101.0}$ & $\overline{102.2}$ & $\overline{102.9}$ & $\overline{100.4}$ & $\overline{99.3}$ & 100.1 & 102.7 & $\overline{101.3}$ & \\
\hline ACNK & 1.11 & 1.21 & 3.85 & 1.06 & 1.02 & 1.03 & 1.08 & 1.12 & 1.07 & 1.24 & 1.38 & \\
\hline \multicolumn{13}{|c|}{ Trace elements ${ }^{3}$} \\
\hline $\mathrm{Rb}$ & 116 & 138 & 123 & 146 & 146 & 130 & 121 & 132 & 123 & 135 & 131 & 10.2 \\
\hline Cs & 5 & 4 & 7 & 4 & 6 & 4 & 5 & 6 & 6 & 6 & 5 & 1 \\
\hline $\mathrm{Ba}$ & 466 & 486 & 277 & 467 & 386 & 442 & 432 & 385 & 413 & 282 & 404 & 73 \\
\hline $\mathrm{Sr}$ & 226 & 156 & 77 & 147 & 177 & 187 & 273 & 207 & 248 & 166 & 186 & 56 \\
\hline $\mathrm{Ga}$ & 19 & 17 & 19 & 17 & 19 & 18 & 19 & 18 & 19 & 20 & 19 & 1 \\
\hline $\mathrm{Ta}$ & $<0.5$ & 1.7 & $<0.5$ & $<0.5$ & 1.2 & 1.4 & $<0.5$ & 1.1 & 1.2 & 1.0 & 0.9 & 0.3 \\
\hline $\mathrm{Nb}$ & 15 & 16 & 17 & 13 & 15 & 15 & 16 & 19 & 16 & 16 & 16 & 1 \\
\hline $\mathrm{Hf}$ & 4 & 4 & 4 & 3 & 3 & 4 & 4 & 4 & 4 & 4 & 4 & 0.3 \\
\hline $\mathrm{Zr}$ & 158 & 154 & 158 & 148 & 151 & 156 & 168 & 149 & 167 & 161 & 157 & 7 \\
\hline $\mathrm{Y}$ & 17 & 17 & 19 & 14 & 17 & 18 & 18 & 18 & 18 & 18 & 18 & 1 \\
\hline Th & 10.3 & 11.9 & 12.4 & 9.2 & 10.4 & 10.5 & 10.8 & 10.0 & 10.9 & 10.6 & 10.7 & 0.9 \\
\hline $\mathrm{U}$ & 5.8 & 7.1 & 10.1 & 4.5 & 6.5 & 6.1 & 6.7 & 9.5 & 5.7 & 6.1 & 6.8 & 1.7 \\
\hline $\mathrm{La}$ & 25.0 & 26.6 & 28.2 & 24.0 & 24.2 & 23.6 & 21.9 & 26.8 & 23.7 & 23.4 & 24.7 & 1.9 \\
\hline $\mathrm{Ce}$ & 52 & 51 & 58 & 49 & 49 & 48 & 48 & 56 & 50 & 49 & 51 & 3 \\
\hline $\mathrm{Nd}$ & 29 & 33 & 35 & 34 & 22 & 26 & 31 & 31 & 23 & 29 & 29 & 5 \\
\hline $\mathrm{Sm}$ & 3.9 & 3.5 & 4.4 & 3.4 & 3.5 & 3.7 & 3.6 & 4.0 & 3.2 & 3.7 & 3.7 & 0.3 \\
\hline $\mathrm{Eu}$ & 0.9 & 0.7 & 0.7 & 0.7 & 0.5 & 1.1 & 1.0 & 0.9 & 0.9 & 1.0 & 0.8 & 0.2 \\
\hline $\mathrm{Tb}$ & $<0.5$ & $<0.5$ & $<0.5$ & $<0.5$ & $<0.5$ & $<0.5$ & $<0.5$ & $<0.5$ & $<0.5$ & $<0.5$ & & \\
\hline $\mathrm{Yb}$ & 1.9 & 2.2 & 1.9 & 1.3 & 1.9 & 1.9 & 1.9 & 2.0 & 2.0 & 1.9 & 1.9 & 0.2 \\
\hline $\mathrm{Lu}$ & 0.29 & 0.35 & 0.25 & 0.22 & 0.35 & 0.29 & 0.31 & 0.31 & 0.32 & 0.28 & 0.30 & 0.04 \\
\hline $\mathrm{Cr}$ & 30 & 18 & 28 & 4 & 23 & 23 & 22 & 5 & 23 & 28 & 20 & 9 \\
\hline $\mathrm{Ni}$ & 14 & 10 & 20 & 10 & 12 & 14 & 14 & 9 & 12 & 16 & 13 & 3 \\
\hline $\mathrm{Co}$ & 8 & 7 & 7 & 3 & 7 & 7 & 7 & 5 & 7 & 6 & 6 & 1 \\
\hline $\mathrm{Sc}$ & 7.3 & 6.6 & 7.7 & 4.7 & 6.5 & 7.3 & 7.5 & 5.5 & 7.3 & 6.9 & 6.7 & 1.0 \\
\hline $\mathrm{V}$ & 65 & 57 & 83 & 32 & 60 & 66 & 55 & 35 & 57 & 55.0 & 56.4 & 14.6 \\
\hline $\mathrm{Cu}$ & 130 & 112 & 136 & 125 & 148 & 160 & 58 & 23 & 108 & 118 & 112 & 42 \\
\hline $\mathrm{Pb}$ & 16 & 20 & $<0.53$ & 24 & 16 & 12 & 20 & 39 & 15 & 12 & 19 & 8 \\
\hline $\mathrm{Zn}$ & $<50$ & $<50$ & 60 & $<50$ & $<50$ & $<50$ & $<50$ & $<50$ & $<50$ & $<50$ & & \\
\hline W & $<1$ & $<1$ & $<1$ & 2 & 3 & $<1$ & $<1$ & $<1$ & $<1$ & $<1$ & & \\
\hline Mo & 4 & 7 & 12 & $<1$ & 11 & $<1$ & $<1$ & $<1$ & 7 & 5 & 5 & 3 \\
\hline $\mathrm{Ag}$ & $<5$ & $<5$ & $<5$ & $<5$ & $<5$ & $<5$ & $<5$ & $<5$ & $<5$ & $<5$ & & \\
\hline As & 8.6 & 46 & 685 & 295.5 & 92.1 & 16.7 & 7.5 & 44.4 & 35.2 & 12 & 124 & 215 \\
\hline Se & $<3$ & $<3$ & $<3$ & $<3$ & $<3$ & $<3$ & $<3$ & $<3$ & $<3$ & $<3$ & & \\
\hline $\mathrm{Sb}$ & 12 & 30 & 630 & 28 & 20 & 33 & 5 & 10 & 9 & 23 & 80 & 193 \\
\hline $\mathrm{Br}$ & $<0.5$ & $<0.5$ & $<0.5$ & $<0.5$ & $<0.5$ & $<0.5$ & $<0.5$ & $<0.5$ & $<0.5$ & $<0.5$ & & \\
\hline $\mathrm{Cl}$ & 55 & 67 & 77 & 74 & 66 & 42 & 79 & 83 & 43 & 61 & 65 & 15 \\
\hline $\mathrm{Hg}$ & $<1$ & $<1$ & $<1$ & $<1$ & $<1$ & $<1$ & $<1$ & $<1$ & $<1$ & $<1$ & & \\
\hline $\mathrm{Au}$ & 46 & 36 & 31 & 29 & 8 & $<2$ & 3 & $<2$ & 39 & 12 & 25 & 16 \\
\hline$S^{4}$ & 5225 & 4244 & 4864 & 2459 & 3453 & 3822 & 1802 & 1062 & 4043 & 1562 & 3254 & 1447 \\
\hline$S^{5}$ & 107 & 105 & 57 & 57 & 94 & 57 & 85 & 47 & 41 & 41 & 69 & 26 \\
\hline $\mathrm{MS}^{6}$ & 320 & 1350 & 150 & 110 & 750 & 220 & 600 & 150 & 900 & 600 & 515 & 404 \\
\hline$\delta S(\%)$ & 1.4 & 1.2 & -0.7 & 0.5 & 0.8 & 0.5 & 3.4 & 1.6 & 1.4 & 0.3 & 1.0 & 1.1 \\
\hline
\end{tabular}

Notes: 1. Major and minor oxides are given as weight percent. 2. L.O.I. = Loss on ignition. 3. Trace element analyses all in ppm except Au which is in ppb. 4. XRF analysis of pressed pellet. 5. XRF analysis of fused disk. 6. MS = Magnetic susceptibility in SI units $\left(\mathrm{x} 10^{5}\right)$. 
that it plots as in the quartz-rich granitoid field and has much lower $\mathrm{CaO}$ and $\mathrm{Na}_{2} \mathrm{O}$ contents ( 0.41 and $0.22 \%$, respectively), suggesting that the sample has been strongly altered; it contains altered xenoliths of similar composition (see also sample 81-26-63.4).

The $\mathrm{Nb}$ versus $\mathrm{Y}$ and the $\mathrm{Rb}$ versus $\mathrm{Y}+\mathrm{Nb}$ discrimination diagrams (Figs. 9a, b) (Pearce et al. 1984) show that the dyke has a volcanic-arc, I-type granite affinity, similar to the Lake George granodiorite stock (Yang et al. 2002a). Normalized to primitive mantle and chondrite compositions (Fig. 10a, b), the dyke shows negative $\mathrm{Ba}$ (ave. $404 \mathrm{ppm}$ ), $\mathrm{Nb}$ (ave. $16 \mathrm{ppm}$ ), $\mathrm{TiO}_{2}$ (ave. 0.54 wt. \%), and $\mathrm{Sr}$ (ave. $186 \mathrm{ppm}$ ) anomalies.

Multi-element (spider) and chondrite-normalized REE patterns for the QFP dyke and proximal plutonic units (Fig. $10 \mathrm{a}, \mathrm{b}$ ) are similar with notable negative $\mathrm{Ba}, \mathrm{Nb}, \mathrm{P}$, and weak Ti anomalies. The spider diagrams also show that sample DDH81-21-181.1 (fractured) and sample DDH 81-26-63.4 (dark glassy matrix) are similar in composition to the other samples despite textural differences. The QFP dyke most closely resembles the Lake George granodiorite and the Hawkshaw granite (Fig. 11a, b). The La/Yb ratios for these units are also similar $(13.0,14.4,15.2$, respectively), whereas the ratios for the Hartfield tonalite (16.5) and the Skiff Lake granite (14.6) are relatively higher. The lower LREE and HREE abundances in the QFP dyke, granodiorite stock, and Hawkshaw granite, relative to more primitive phases of the Pokiok Batholith, suggest low temperature fractionation process (e.g., Miller and Mittlefehldt 1982).

The $\mathrm{Rb}, \mathrm{Ba}$, and $\mathrm{Sr}$ ternary diagram (Fig. 12) shows the differentiation trend in the Pokiok Batholith. Based on wholerock compositions, Sr content should decrease, whereas Ba increases within a differentiating intermediate to felsic system (el Bouseily and el Sokkary 1975). The Rb-Ba-Sr diagram shows that the Hartfield tonalite is the most primitive (oldest) and the Allandale granite is the most differentiated unit of the batholith, although the latter unit likely represents a separate magmatic event, based on its much younger age. However, this diagram displays some scatter for the Lake George granodiorite and QFP dyke samples, attributed to alteration.

Although zircon saturation thermometry was not used due to the possibility of inheritance, it is notable that the Hartfield tonalite and the Skiff Lake and Hawkshaw granite units exhibit decreasing $\mathrm{Zr}$ and $\mathrm{TiO}_{2}$ (Fig. 13), consistent with fractional crystallization. This variation is consistent with the saturation behaviour of zircon in crystallizing granitic magmas (Hanchar and Watson 2004), and the decreasing REE contents noted above.

The average $S$ content determining using pressed pellet XRF analysis is $3250 \pm 1450 \mathrm{ppm}$; compared to the results from the fused bead method, the data indicate that $S$ is dominantly tied up in sulphide minerals. The average $\delta^{34} S$ for the bulk $S$ contents of the QFP dykes is $1.0 \pm 1.1 \%$ (Table 2); this narrow range near typical mantle values in a reduced I-type intrusion (Ohmoto and Goldhaber 1997) is consistent with a high-T magmatic origin for the sulphide minerals, with negligible fractionation evident (see detailed discussion in Yang 2005).

$\mathrm{Au}(<2$ to 46 , average $20 \mathrm{ppb}), \mathrm{W}(<1$ to $3 \mathrm{ppm})$, and $\mathrm{Mo}(<1$ to 11 , average $7 \mathrm{ppm}$ ) contents in the QFP dyke are substantially lower than averages for the Lake George granodiorite (32 ppb, 9, and 7 ppm, respectively; Yang et al. 2002a). The average $\mathrm{Cu}$ abundance $(112 \pm 42 \mathrm{ppm})$ in the QFP dyke is notably higher than in the Lake George granodiorite (average $41 \pm 38 \mathrm{ppm})$. S abundance co-varies with both $\mathrm{Au}$ and $\mathrm{Cu}$ (Fig. 14), supporting a deuteric origin for the $S$ and metal enrichment; these data are consistent with the observations of Stirling (1979) of S enrichment in the most quenched contact zones of a similar dyke. Average $\mathrm{Sb}(80 \pm 193 \mathrm{ppm})$ and As $(124 \pm 215 \mathrm{ppm})$ contents are significantly higher in the dyke than in the Lake George granodiorite, indicative of alteration, but they are unrelated to $\mathrm{S}, \mathrm{Cu}$, and $\mathrm{Au}$ abundance based on their low correlation coefficients $(<0.3)$. However, all of these values are above crustal averages (Wedepohl 1995) and point to enrichment associated with magmatic volatiles related to emplacement of the QFP dyke.

\section{GEOTHERMOMETRY}

In terms of magma geothermometry, apatite saturation temperature (AST) calculated using $\mathrm{P}_{2} \mathrm{O}_{5}$ abundance and compositional corrections was estimated for the Lake George granodiorite to be $902 \pm 14^{\circ} \mathrm{C}$. This temperature is interpreted to represent a melt temperature with apatite as a liquidus phase (Yang et al. 2002b). Similarly, apatite also occurs as a liquidus

Table 3. U-Pb data for the QFP dyke (DDH 81-21) at the Lake George antimony mine, New Brunswick.

\begin{tabular}{|c|c|c|c|c|c|c|c|c|c|c|c|c|c|c|c|c|c|}
\hline \multirow[b]{2}{*}{ Grain } & \multirow[b]{2}{*}{ Desc. } & \multirow[b]{2}{*}{$\begin{array}{l}\text { Wt. } \\
(\mathrm{mg})\end{array}$} & \multirow[b]{2}{*}{$\begin{array}{c}\mathrm{U} \\
(\mathrm{ppm})\end{array}$} & \multirow[b]{2}{*}{$\frac{T h}{U}$} & \multirow[b]{2}{*}{$\begin{array}{c}\mathrm{Pb}^{*} \\
(\mathrm{ppm})\end{array}$} & \multirow[b]{2}{*}{$\begin{array}{c}\text { Comm. } \\
\mathrm{Pb} \\
(\mathrm{pg})\end{array}$} & \multirow[b]{2}{*}{$\frac{{ }^{206} \mathrm{~Pb}}{{ }^{204} \mathrm{~Pb}}$} & \multirow[b]{2}{*}{$\frac{{ }^{206} \mathrm{~Pb}}{{ }^{238} \mathrm{U}}$} & \multirow[b]{2}{*}{$\begin{array}{c} \pm \\
(2 \sigma \%)\end{array}$} & \multirow[b]{2}{*}{$\frac{{ }^{207} \mathrm{~Pb}}{{ }^{235} \mathrm{U}}$} & \multirow[b]{2}{*}{$\begin{array}{c} \pm \\
(2 \sigma \%)\end{array}$} & \multirow[b]{2}{*}{$\frac{{ }^{207} \mathrm{~Pb}}{{ }^{206} \mathrm{~Pb}}$} & \multirow[b]{2}{*}{$\begin{array}{c} \pm \\
(2 \sigma \%)\end{array}$} & \multicolumn{3}{|c|}{ Ages } & \multirow[b]{2}{*}{$\begin{array}{c}\text { Conc. } \\
\%\end{array}$} \\
\hline & & & & & & & & & & & & & & $\frac{{ }^{206} \mathrm{~Pb} /}{{ }^{238} \mathrm{U}}$ & $\frac{{ }^{207} \mathrm{~Pb} /}{{ }^{235} \mathrm{U}}$ & $\frac{\frac{{ }^{207} \mathrm{~Pb} /}{{ }^{206} \mathrm{~Pb}}}{}$ & \\
\hline $\mathrm{Zr} 1$ & $2 \mathrm{Pr}$ & 0.015 & 284 & 0.23 & 18.3 & 10 & 869.0 & 0.0662 & 0.35 & 0.5042 & 0.36 & 0.05525 & 0.16 & 413 & 415 & 422 & 97.8 \\
\hline $\operatorname{Zr} 2$ & $1 \mathrm{Pr}$ & 0.009 & 117 & 0.35 & 7.8 & 8 & 539.5 & 0.0664 & 0.31 & 0.5047 & 0.45 & 0.05511 & 0.36 & 415 & 415 & 417 & 99.4 \\
\hline $\operatorname{Zr} 3$ & $2 \mathrm{Rd}$ & 0.018 & 127 & 0.29 & 11.4 & 6 & 2303.4 & 0.0924 & 0.27 & 0.8209 & 0.60 & 0.06446 & 0.54 & 569 & 609 & 757 & 74.1 \\
\hline $\operatorname{Zr} 4$ & $1 \mathrm{Pr}$ & 0.01 & 455 & 0.30 & 29.5 & 7 & 2549.1 & 0.0652 & 0.28 & 0.4951 & 0.28 & 0.05507 & 0.20 & 407 & 408 & 415 & 98.0 \\
\hline Zr 5 & $2 \operatorname{Pr}$ & 0.03 & 471 & 0.37 & 30.2 & 9 & 2925.4 & 0.0629 & 0.30 & 0.4784 & 0.29 & 0.05513 & 0.12 & 393 & 397 & 417 & 94.1 \\
\hline
\end{tabular}

$\mathrm{Pr}=$ prismatic $\mathrm{Rd}=$ Rounded; $1=1$ zircon; 2 = 2 zircons; $\mathrm{Pb}^{*}=$ Radiogenic $\mathrm{Pb}$ 


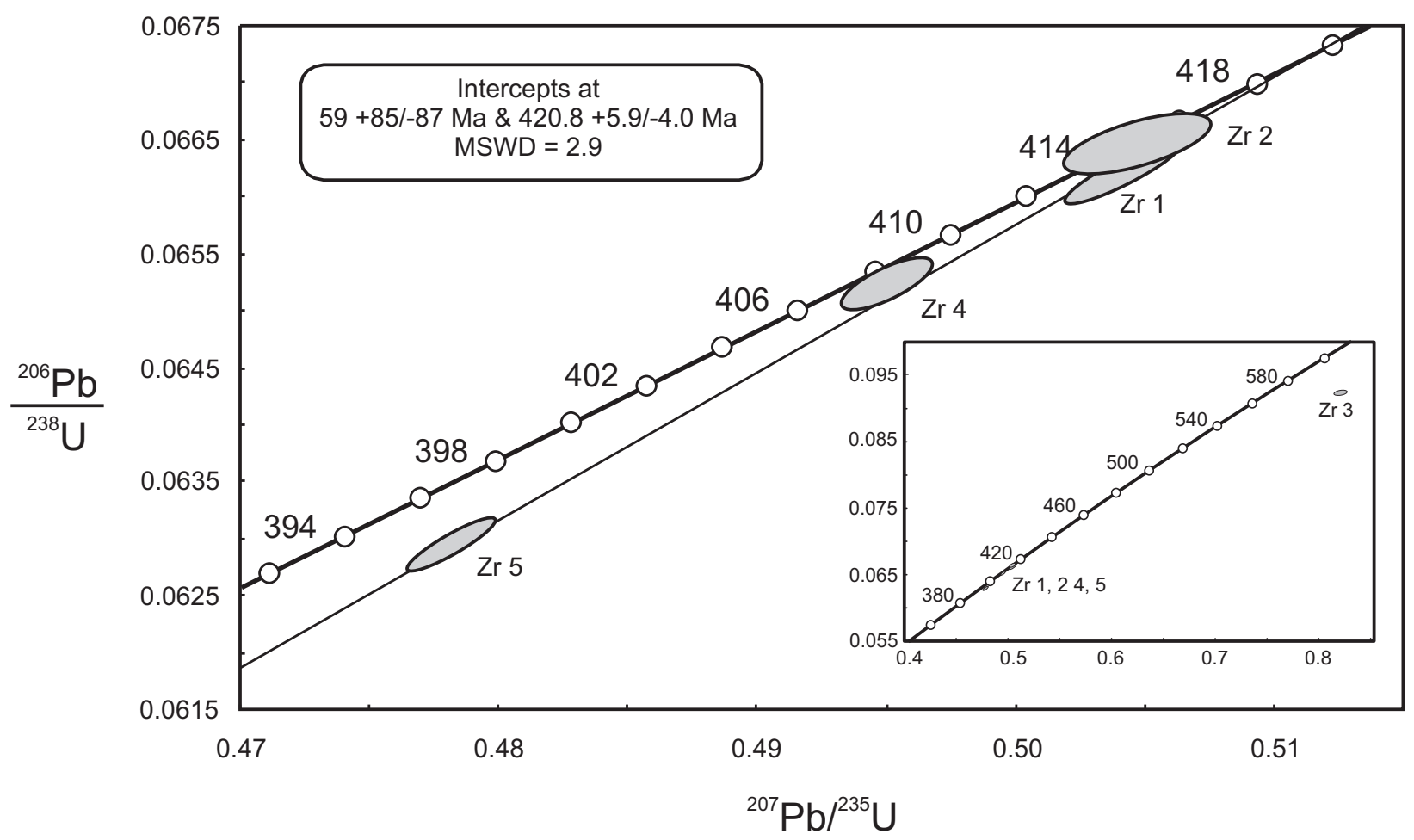

Fig. 7 U-Pb concordia diagrams for five zircon fractions from the QFP dyke at Lake George (DDH 81-21)(see Table 3 and Appendix). Data point error ellipses are reported at $2 \sigma$.

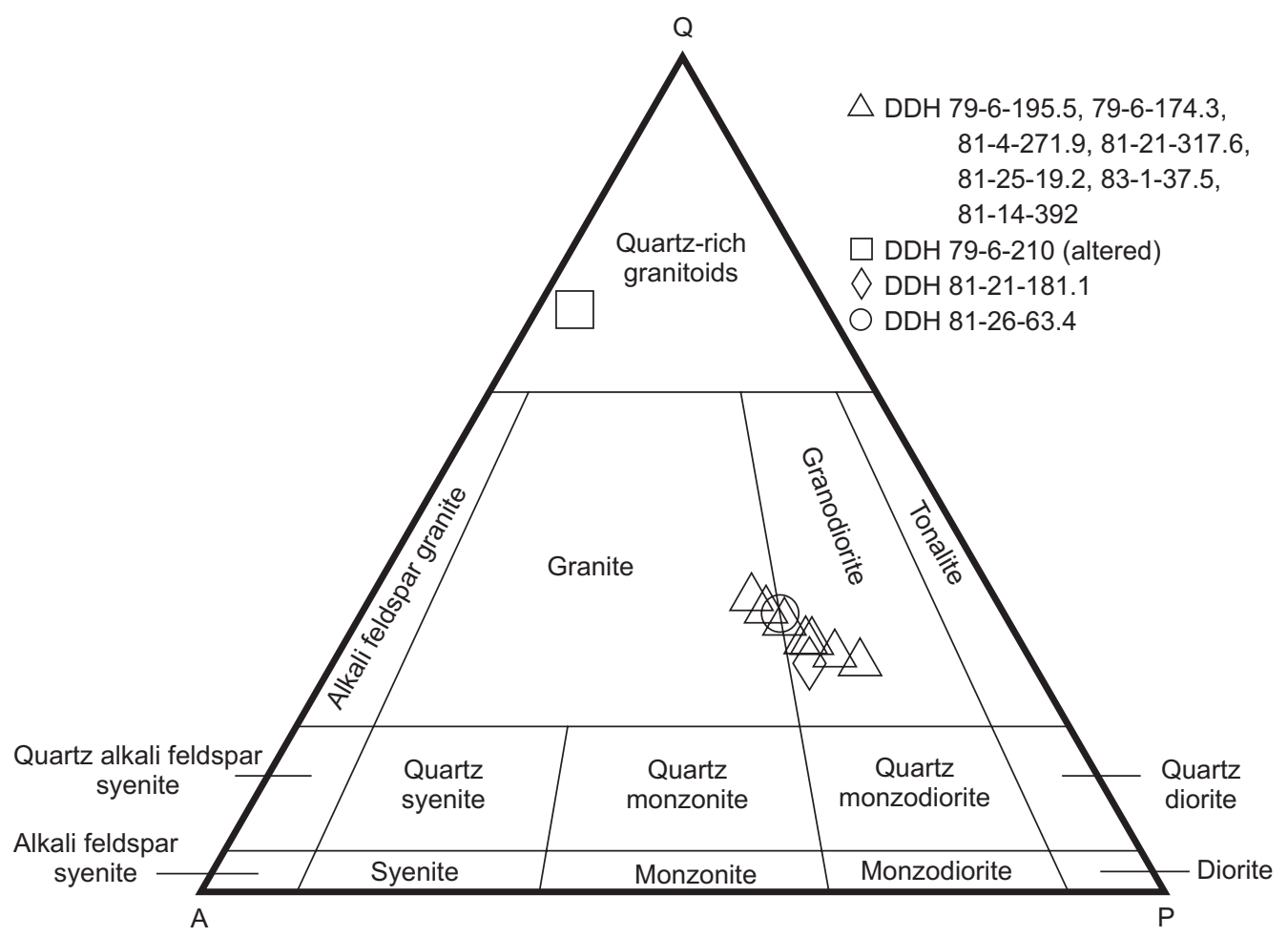

Fig. 8 QAP diagram (LeMaitre et al. 1989) based on CIPW norms for the QFP dyke at Lake George, New Brunswick. 

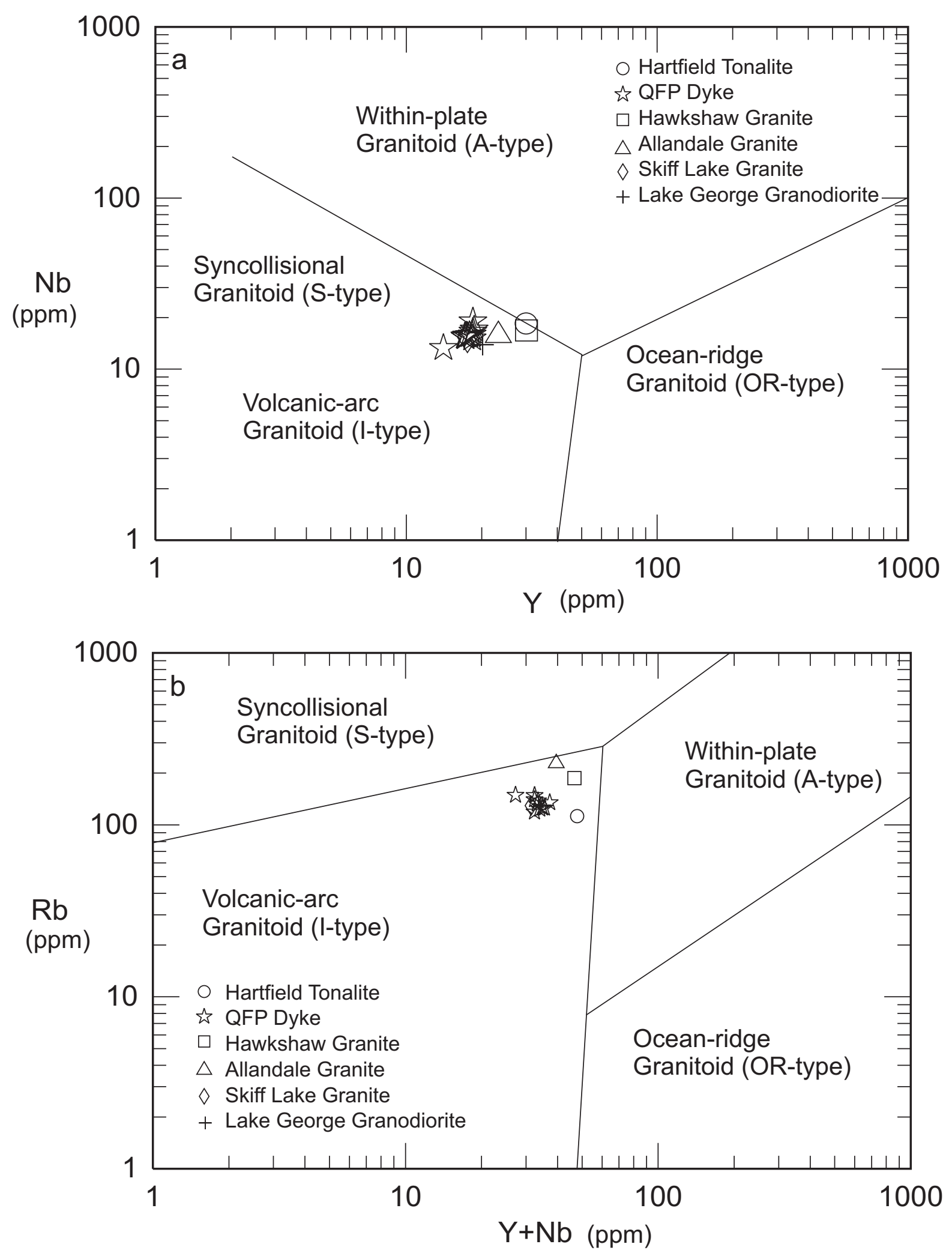

Fig. 9 Trace-element geotectonic discrimination diagrams (after Pearce et al. 1984; Christiansen and Keith 1996). a) Nb versus $\mathrm{Y}$ diagram and $\mathrm{b}$ ) $\mathrm{Rb}$ versus $\mathrm{Nb}+\mathrm{Y}$ including averages from units of the Pokiok Batholith compared to the QFP dyke and Lake George granodiorite (see Yang et al. 2002a). Data from the Pokiok Batholith are from Whalen (1993). 
phase in the QFP dyke (this study) and in units of the Pokiok Batholith (i.e., Hartfield, Skiff Lake, Hawkshaw, and Allandale granitoids) (Lutes 1987; Whalen 1993; Yang et al. 2002a, b). Thus, we calculated liquidus temperatures for these granitoids using AST (Harrison and Watson 1984) information which may help constrain their genetic relations. Average AST values for the QFP dyke, Hartfield, Skiff Lake, Hawkshaw, and Allandale granitoids are $902^{\circ}, 909^{\circ}, 955^{\circ}, 958^{\circ}$, and $982^{\circ} \mathrm{C}$, respectively. The similarity in AST between the dyke and the units of the batholith suggests that they may be genetically related, consistent with compositional similarities. AST decreases from
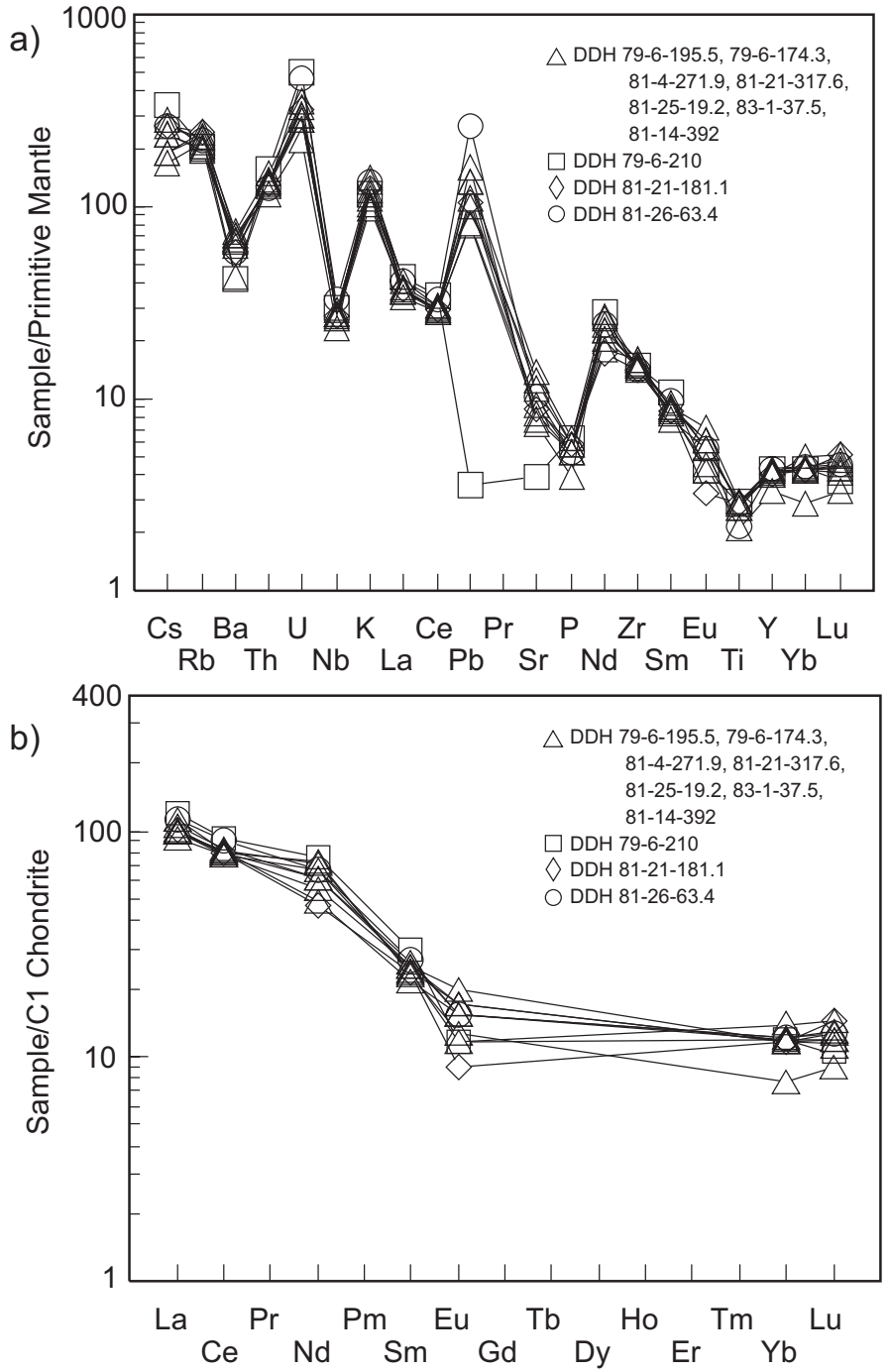

Fig. 10 (a) Primitive mantle-normalized, trace-element spider diagrams for the QFP dyke. The primitive mantle values are from McDonough and Sun (1995). (b) Chondrite-normalized rare-earth-element spider diagram for the QFP dyke at Lake George. The chondrite-normalizing values are from McDonough and Sun (1995). the Hawkshaw granite $\left(958^{\circ} \mathrm{C}\right)$ to the QFP dyke and stock $\left(902^{\circ} \mathrm{C}\right.$ ), consistent with fractional crystallization (cf. Yang et al. 2002a).

\section{DISCUSSION}

\section{Textural constraints on crystallization}

No change is perceptible in groundmass texture or grain size in the dyke at depth relative to near-surface samples, al-
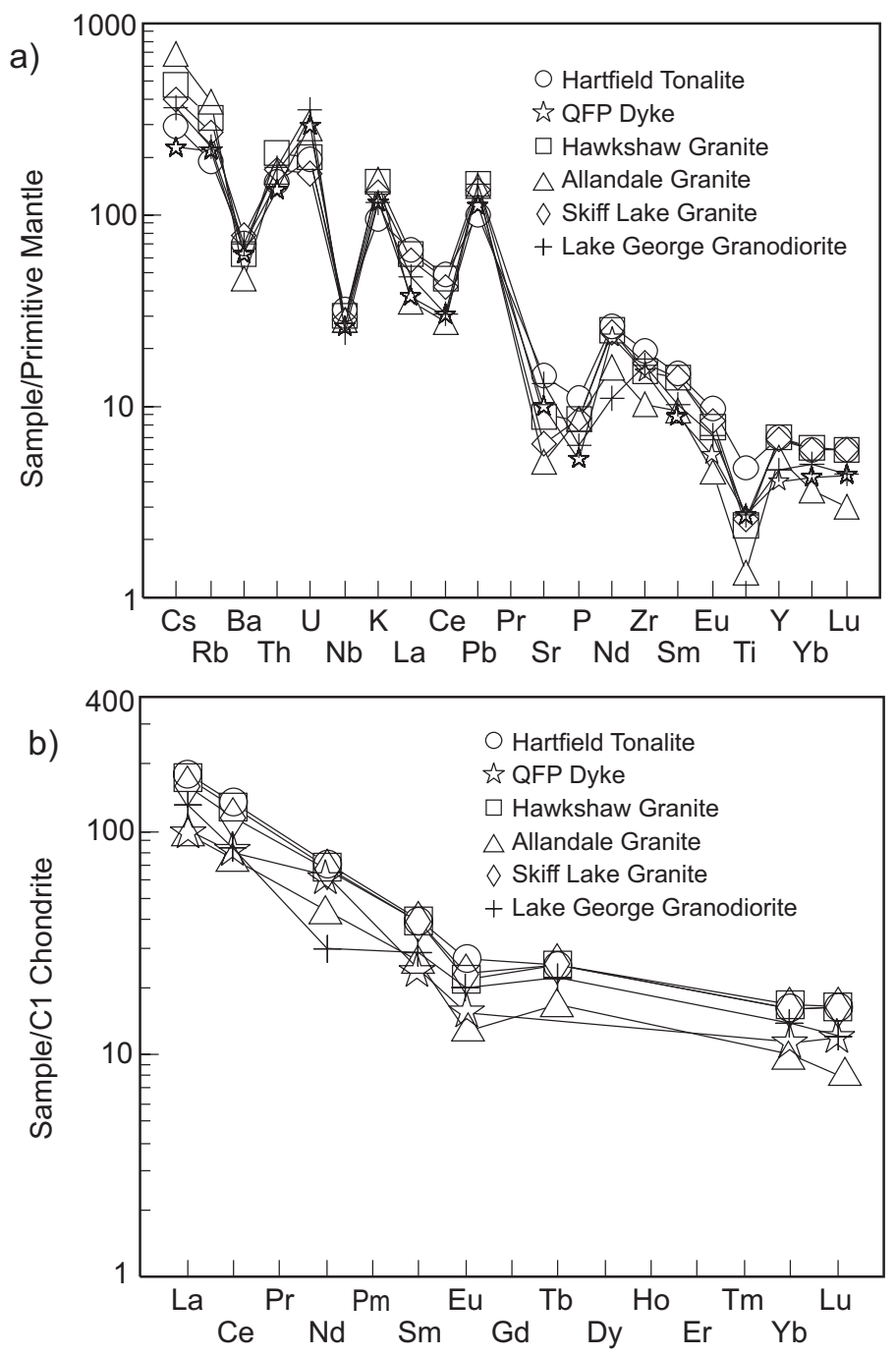

Fig. 11 (a) Primitive mantle-normalized, trace-element spider diagram for phases of the Pokiok Batholith, QFP dyke, and Lake George granodiorite. The primitive mantle values are from McDonough and Sun (1995). (b) Chondrite-normalized rare-earth-element patterns for the Pokiok Batholith, QFP dyke, and Lake George granodiorite. The chondritenormalizing values are from McDonough and Sun (1995). 


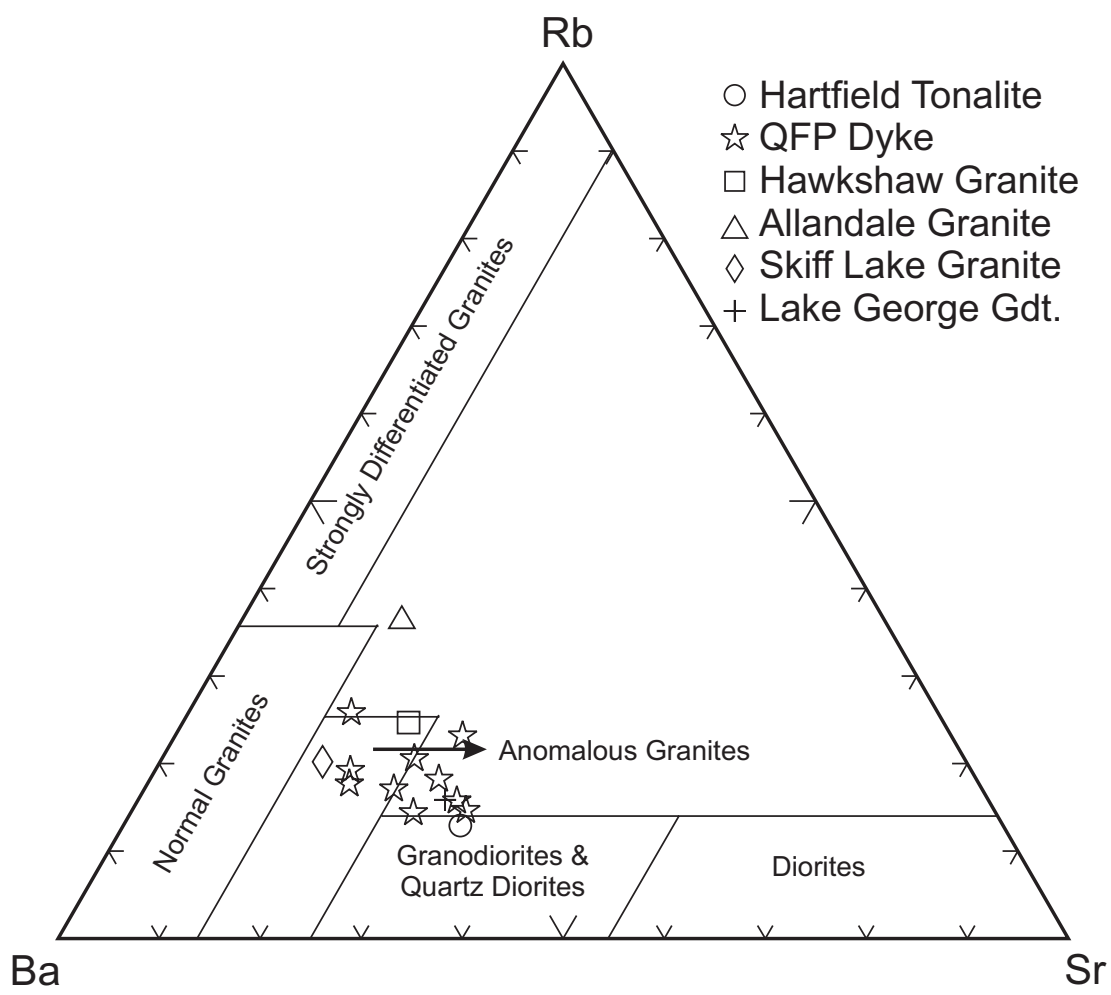

Fig. 12 Rb-Ba-Sr ternary diagram of el Bouseily and el Sokkary (1975) for the QFP dyke at Lake George plotted with the five units of the Pokiok Batholith and Lake George granodiorite (data from Whalen 1993; Yang et al. 2002a).

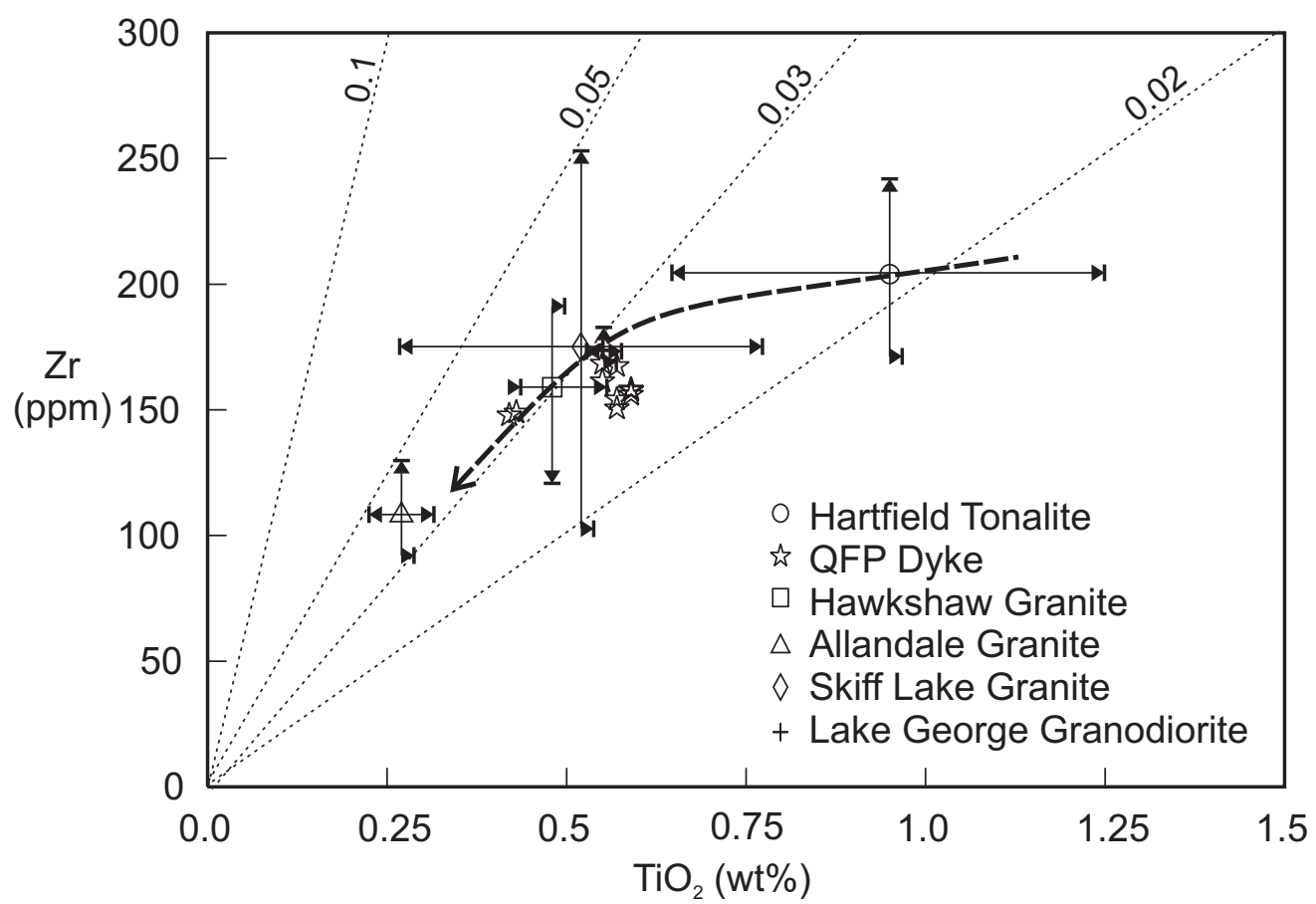

Fig. $13 \mathrm{Zr}$ versus $\mathrm{TiO}_{2}$ plot of the QFP dyke at Lake George, as well as average and range (SD) for related intrusive units in the area (data from Whalen 1993; Yang et al. 2002b). The vector is the interpreted fractionation array, with $\mathrm{Zr} / \mathrm{TiO}_{2}$ ratios illustrated. 


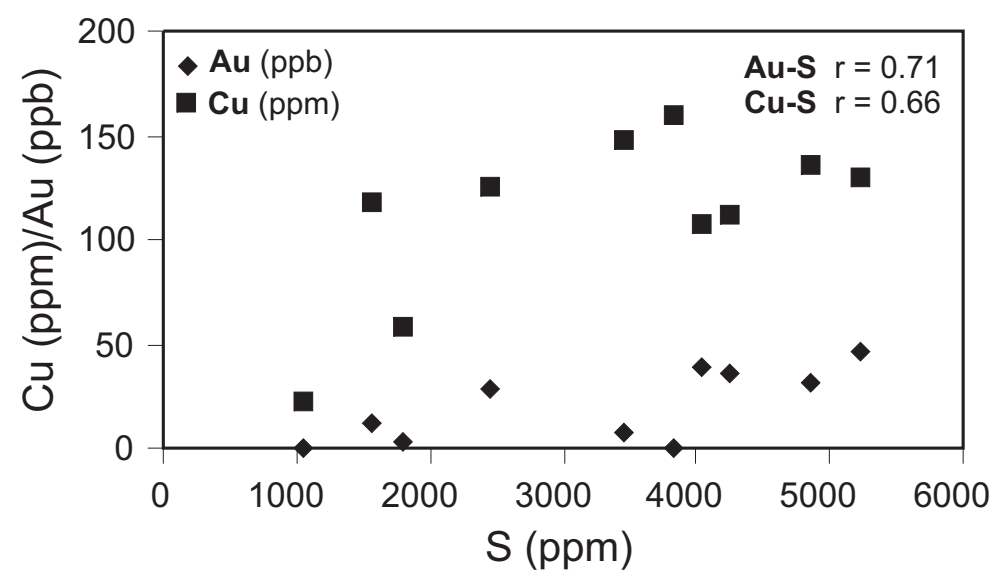

Fig. $14 \mathrm{~S}$ versus $\mathrm{Au}$ and $\mathrm{Cu}$ abundances in the QFP dyke at Lake George. The r values are calculated Pearson Product correlation coefficients.

though the dyke margins exhibit more auto-brecciation. The groundmass is recrystallized and hydrothermally altered to a variable degree, probably reflecting the autometasomatic effects of deuteric fluids, as well as the slightly later contact metamorphic and metasomatic effects of intrusion of the Lake George granodiorite and antimony vein mineralization in the area. Phenocrysts of subhedral to rounded feldspar and quartz are common in both the dyke and Lake George granodiorite (Yang et al. 2002b). Rounded phenocrysts suggest that quartz and plagioclase were partially remelted (depressurization) and (or) were abraded mechanically during rapid emplacement. The subrounded quartz phenocrysts form composite crystals that are fused together locally. No evidence of gas cavities is preserved. The altered granitic fragments $(0.5$ to $>10 \mathrm{~cm}$ in diameter) near the QFP dyke margins are subangular to rounded and possibly recrystallized; these fragments probably represent the fractionated roof zone to this intrusion and (or) autobrecciated products of the margin of the dyke itself, as they have the same bulk composition as the dyke. Although angular to rounded wall rock fragments exist, they were avoided during sampling.

The oscillatory normal zoning in plagioclase (Fig. 4) (An 43 to 53) is interpreted as the result of diffusion-controlled growth locally interrupted by magma replenishment and possible resorption in the subvolcanic magma chamber before dyke emplacement. Zoning of plagioclase was obscured during periods of uneven resorption of the grains, which resulted in a rounded zoning pattern. SEM-EDS analysis across zoned plagioclase grains (Fig 4) in sample DDH 81-62-63.4 shows variations in $\mathrm{Ab}$ and An within each subzone, reflecting variation in crystallization and/or melt diffusion rates of $\mathrm{Na}$ and $\mathrm{Ca}$ (Table 1). The centres of the plagioclase phenocrysts contain an unzoned homogeneous core, indicating that during this period crystallization was slower to allow diffusion across the grain. The textures present in the plagioclase from the Lake George granodiorite stock are similar to those in the QFP dyke (Seal et al. 1988; Yang et al. 2002a).

It was concluded earlier that the source magma for the granodioritic intrusion and QFP dyke crystallized amphibole and biotite during its ascent (Yang et al. 2002b). The absence of amphibole in the dyke suggests that the amphibole phenocrysts were directly replaced by biotite, i.e., biotite became a liquidus phase at the expense of hornblende in the presence of evolving melt at lower temperature (see Naney 1983), or fractionation removed amphibole from the dyke-forming magma. If amphibole partitioned higher amounts of HREE, their absence in the dyke would be indicated by a noticeable decrease in HREE (Barker 1979). The expected relative decrease in HREE is not evident between the granodioritic intrusion and the dyke (Fig. 12), suggesting that the lack of amphibole was not due to fractionation. The geochemical similarity between the QFP dyke and the Lake George granodiorite stock suggests that the parental magma of the dyke was hornblende bearing. As can be seen on the chondrite-normalized REE diagram (Fig. $12 \mathrm{~b}$ ), a lower abundance of total REE and LREE is present in younger units of the Pokiok Batholith. The decrease in LREE with fractionation supports apatite (and titanite \pm monazite) as liquidus phases, possibly enhanced by an association with ferromagnesian phases.

Reddish-brown (reduced) biotite was observed as inclusions within quartz phenocrysts, although it was not observed in plagioclase; chlorite (the main product of biotite alteration) was also observed as inclusions in quartz. These observations support the interpretation that biotite was present when these phenocrysts crystallized, although they look sutured and anhedral possibly due to destabilization during emplacement/ depressurization.

The euhedral titanite crystals in the dyke are of igneous origin, as are the rare ilmenite crystals. The inclusions in the titanite are likely the result of hydrothermal alteration, although some may have been entrapped during episodes of crystallization and regrowth. The zoning and resorption surfaces in titanite suggest an evolving magmatic system that may have resulted from changes in melt composition due to fractionation or could indicate that Ti enrichment occurred on more than one occasion. Regardless of possible Ti enrichment, the presence of ilmenite, titanite, rutile, and Ti-rich biotite appear to reflect high Ti contents in the dyke-forming magma. 
The assemblage titanite-magnetite-quartz-pyrrhotite may be a late auto-oxidation and sulphidation product of vapour exsolution (Candela 1991), as it is not consistent with high $\mathrm{Fe}$ (-Ti) biotite (Wones 1981).

Magmatic pyrrhotite phenocrysts may have crystallized under reducing conditions in the magma, although they would have segregated quickly and lowered the base-metals and gold abundance. Presently, the $S$ abundance in the QFP dyke is almost 10 times greater than the $S$ solubility in granitoid magmas at $1000^{\circ} \mathrm{C}$ (Ohmoto and Goldhaber 1997). Therefore pyrrhotite formation at late stages of crystallization related to alteration with $\mathrm{H}_{2} \mathrm{~S}$-bearing magmatic fluids better explains the $S$ abundances and isotopic signatures observed. Gold distribution and abundance, relative to that of $S$ and other metals, in igneous rocks provides important information about the potential for associated gold mineralization (cf. Müller and Groves 2000 and references therein).

\section{Dyke emplacement constraints}

The presence of quartz and two feldspar phenocrysts in the stock and dyke implies high $\mathrm{P}\left(\mathrm{H}_{2} \mathrm{O}\right)(>3 \mathrm{~kb}$; Martin and Bonin 1976) in the magma before final emplacement. Considering the lack of marginal quenching and flow foliation, as well as the rheology of the phenocryst-rich siliceous magma (discussed below), it is probable that exsolved gases from the magma (fluidization) enhanced dyke emplacement (Clarke 1992); fluidization is consistent with the angular to subrounded nature of xenoliths and the rounding and fragmentation of phenocrysts that are now best described as phenoclasts. The fine-grained groundmass and minor granophyric (wormy) to more prevalent graphic (cuneiform) texture resulted from quench crystallization (low degrees of supercooling) of the dyke, possibly enhanced by vapour exsolution and depressurization (see Fenn 1986; Lentz and Fowler 1992). The highest level dyke samples exhibit microcrystalline texture consisting of intergrown fibrolites rimming quartz and feldspar phenocrysts, reflecting greater degrees and rates of supercooling or devitrification(Stirling 1981; MacLellan and Trembath 1991), akin to aplite.

Calculated cooling rates using a conductive thermal cooling model (HEAT, Wohletz and Heiken 1991) for this vertical $5 \mathrm{~m}$-wide QFP dyke (initial $1000^{\circ} \mathrm{C}$ liquidus temperature, see below) in a low geothermal gradient $\left(20^{\circ} \mathrm{C} / \mathrm{km}\right)$ reveals that the dyke margins quench to less that $500^{\circ} \mathrm{C}$ in less that 1 day at 1 to $3 \mathrm{~km}$ depth, and that complete solidification $\left(<760^{\circ} \mathrm{C}\right.$ at $1 \mathrm{~kb}$ ) occurs in less than 10 days at $1 \mathrm{~km}$, and 30 days at less than $3 \mathrm{~km}$ (equivalent to $1 \mathrm{~kb}$ ). These figures are consistent with the cooling rates and quench textures in high-level felsic dykes (Stirling 1979). These extremely fast cooling rates in upper crustal thermal gradients should limit the extent of dyke emplacement from its source magma chamber considering melt and effective melt viscosities (cf. Weinberg 1996; Baker 1998).

The calculated viscosity (Shaw 1972) for this magma composition (no crystals) is $4.6 \mathrm{PaS}$ at the calculated liquidus temperature $\left(980^{\circ} \mathrm{C}\right)$ and $1 \mathrm{~kb}$, which decreases to $7.5 \mathrm{PaS}$ at $700^{\circ} \mathrm{C}(1 \mathrm{~kb}, 100 \mathrm{MPa})$. However, the effective viscosity using the Einstein-Roscoe equation (McBirney and Murase 1984) increases dramatically with crystal size and abundance. The effective magma viscosity for $50 \mathrm{vol}$ \% crystals ranges from 24.0 $\mathrm{PaS}$ (1 mm diameter) to $200 \mathrm{PaS}$ ( $1 \mathrm{~cm}$ diameter). However, dyke emplacement pressures are probably considerably less. At 200 bars (20 MPa) vesiculation begins based on conservative water contents of $1.7 \mathrm{wt}$. \%, with critical melt/vapour ratio at 50 bars (> 70 vol. $\%$ gas) with a bulk density of $0.7 \mathrm{~g} / \mathrm{cm}^{3}$; these represent minimum estimates and gas vesiculation probably began much earlier considering the high degree of crystallization (>30 vol. \%) associated with decreasing temperature, so 200 bars $(20 \mathrm{MPa})$ is a reasonable minimum estimate for $\mathrm{H}_{2} \mathrm{O}$ exsolution. The bulk density of the crystallized magma is calculated as $2.5 \mathrm{~g} / \mathrm{cm}^{3}$. The melt-vapour density is approximately $\left(0.7 \mathrm{~g} / \mathrm{cm}^{3}\right)$ at the critical fragmentation pressure $(<20 \mathrm{MPa})$ (magmatostatic). It therefore seems reasonable to expect that a vesiculating hydrous phase was involved in the emplacement of this QFP dyke. Passive to forcible dyke emplacement occurs via fracture propagation (Shaw 1980), possibly enhanced by fluidization (low density, low rheology melt-vapour mixture); the aspect ratio of this dyke ( $5 \mathrm{~m}$ wide by $>1 \mathrm{~km}$ in length, and $>500 \mathrm{~m}$ depth) is also consistent with this emplacement mechanism.

It is possible that the QFP dyke was emplaced along a pre-existing fault or fracture, based on its compositional uniformity, planar attributes, and evidence of auto-brecciation within the dyke (Richards 2001). Initial fracture propagation can occur along a fault (Weinberg 1996), although no offsets are evident relative to the earlier east-trending lamprophyre dykes at the map scale. The lack of evidence for quench crystallization on the margins of the dyke suggests that the degree of undercooling was extreme, possibly even as a glass-gas mixture that subsequently devitrified to produce the observed microcrystalline textures and alteration. The shallow level of dyke emplacement into host rocks at less that $300^{\circ} \mathrm{C}\left(\max .50^{\circ} \mathrm{C} / \mathrm{km}\right.$ for $6 \mathrm{~km}$ or $2 \mathrm{~kb})$ requires a rapid emplacement mechanism (>100 m/day) given the thermal modelling constraints.

\section{CONCLUSIONS}

Although seemingly simple, the QFP dyke has numerous features that help to constrain the emplacement of the magma and understand the role of such subvolcanic bodies in forming the mineralization in the Lake George area.

1) The QFP dyke yielded an age of $420.8+5.9 /-4.0 \mathrm{Ma}$ by $\mathrm{U}-\mathrm{Pb}$ zircon geochronology. Therefore, it is likely genetically related to units of similar age in the Pokiok Batholith, and possibly the Lake George granodiorite stock.

2) The QFP dyke has petrochemical features of a reduced I-type granodiorite, like the Lake George granodiorite stock. Therefore, it is probably a fractionation product of a deeper level unit of the Pokiok Batholith.

3) The presence of two feldspar phenocryst phases supports 
the existence of a deep level ( $>3 \mathrm{~kb}, 300 \mathrm{MPa})$ magma chamber feeding this dyke. Oscillatory zoning in rounded plagioclase phenocrysts/phenoclasts reveals a dynamic system, which caused melting/resorption. This system was likely caused by several episodes of magma mixing or the introduction of fresh magma pulses from the source.

4) Amphibole, which is present in most of the other Pokiok granitoid units, reacted with the fractionated melt to form biotite prior to dyke emplacement. This change explains the similar REE patterns and abundances throughout the Pokiok Batholith, even in the absence of amphibole.

5) Autobrecciation along the margins of the dyke, subrounded fragments, subhedral to rounded and fragmented plagioclase and quartz phenocrysts (phenoclasts), and the autometasomatic effects of deuteric fluids support fluidization (vapour-magma emulsion) as a key emplacement mechanism for the dyke, i.e., analogous to tuffisite. Thermal modelling coupled with integration of the estimated magma properties affecting rheology of this particular system is consistent with these observations.

6) The presence of pyrrhotite ( $>10$ times sulphur saturation levels), which accounts for the range in magnetic susceptibilities, with chalcopyrite (with minor gold) in the QFP dyke was probably produced by high-T subsolidus reactions of deuteric fluids with the quenched walls of the dyke as it was emplaced; this alteration is manifested as alteration in the microcrystalline groundmass. The sulphur isotopic signature $\left(\delta^{34} \mathrm{~S}=1.0\right.$ $\pm 1.0 \%)$ and $S$ abundance $(3250 \pm 1450 \mathrm{ppm})$ indicate that magmatic volatiles were directly involved during dyke emplacement (autometasomatic) and by inference that $\mathrm{Cu}$ and $\mathrm{Au}$ were associated with these volatile components.

\section{ACKNOWLEDGMENTS}

The authors thank Douglas Hall for his guidance and expertise with the SEM at the Electron Microscopy Unit with the University of New Brunswick. Comments on an early version of the manuscript by Warna Downey, Sean McClenaghan, and Xueming Yang were greatly appreciated. APOCAN granted access to drill core. This research was funded by a Discovery grant from the Natural Sciences and Engineering Research Council of Canada and a New Brunswick Department of Natural Resources-minerals research grant and New Brunswick Innovation Funding to D.R. Lentz. The manuscript benefited significantly from critical reviews by Joseph Whalen and Les Fyffe and the journal editor.

\section{REFERENCES}

BAKER, D.R. 1998. Granitic melt viscosity and dike formation. Journal of Structural Geology, 20, pp. 1395-1404.

BARKER, F. 1979. Trondhjemite: Definition, environment and hypotheses of origin. In Trondhjemites, dacites and related rocks. Edited by F. Barker. Amsterdam, Elsevier, pp.1-12.
Bevier, M. L., \& Whalen, J. B. 1990a. U-Pb geochronology of Silurian granites, Miramichi terrane, New Brunswick. In Radiogenic Age and Isotopic Studies: Report 3, Geological Survey of Canada, Paper 89-2, pp. 93-100.

Bevier, M. L., \& Whalen, J. B. 1990b. Tectonic significance of Silurian magmatism in the Canadian Appalachians. Geology, 18, pp. 411-414.

CANDELA, P.A. 1991. Felsic magmas, volatiles, and metallogenesis. In Ore deposition associated with magmas. Edited by J.A. Whitney and A.J. Naldrett. Reviews in Economic Geology, 4, pp. 223-233.

Caron, A. 1996. Geology of the Pokiok Batholith aureole, with emphasis on the Lake George Mine, York County, New Brunswick. New Brunswick Department of Natural Resources and Energy, Minerals and Energy, Geoscience Report 94-2, $91 \mathrm{p}$.

Christiansen, E.H., \& Keith, J.D. 1996. Trace-element systematics in silicic magams: a metallogenic perspective. In Trace Element Geochemistry of Volcanic Rocks: Applications for Massive Sulfide Exploration. Edited by D.A. Wyman. Geological Association of Canada, Short Course Notes 12, pp. 115-151.

Clarke, D.B. 1992. Granitoid rocks. London, Chapman \& Hall, 283 p.

Dubé, B., Dunning, G.R., Lauziere, K., \& Roddick, J.C. 1996. New in-sights into the Appalachian orogen from geology and geochronology along the Cape Ray fault zone southwest Newfoundland. Geological Society of America Bulletin, 108, pp. 101-116.

El Bouseily, A. M., \& El Sokkary, A. A. 1975. The relation between $\mathrm{Rb}, \mathrm{Ba}$ and $\mathrm{Sr}$ in granitic rocks. Chemical Geology, 16, pp. 207-219.

Fenn, P.M. 1986. On the origin of graphic granite. American Mineralogist, 71, pp. 325-330.

Hanchar, J.M., \& Watson, E.B. 2004. Zircon saturation thermometry. Reviews in Mineralogy \& Geochemistry, 53, pp. 89-112.

Harrison, T.M., \& Watson, E.B. 1984. The behavior of apatite during crustal anatexis: equilibrium and kinetic considerations. Geochimica et Cosmochimica Acta, 48, pp. 1467-1477.

IsHIHARA, S. 1981. The granitoid series and mineralization. Economic Geology $75^{\text {th }}$ Anniversary Issue, pp. 458-484.

KROGH, T.E. 1982. Improved accuracy of U-Pb ages by the creation of more concordant systems using an air abrasion technique. Geochimica et Cosmochimica Acta 46, pp. 617-649.

Le Maitre, R.W., Bateman, P., Dudek, A., Keller, J., Lameyre, J., Le Bas, M.J., Sabine, P.A., Schmid, R., SoRensen, H., Streckeisen, A., Wooley, A.R., \& Zanettin, B. 1989. A Classification of Igneous Rocks and Glossary of Terms, Blackwell, Oxford, 193 p.

Lentz, D.R., \& Fowler, A.D. 1992. A dynamic model for graphic quartz-feldspar intergrowths in granitic pegmatites in the southwestern Grenville Province. Canadian Mineralogist, 30, pp. 571-585. 
Lentz, D.R., Thorne, K., \& Yang, X. 2002a. Preliminary analysis of the controls on the various episodes of gold mineralization at the Lake George antimony deposit, New Brunswick. Mineral Resource Report, MRR 2002-4, pp. 55-79.

Lentz, D.R., Thorne, K.G., Yang, X., \& Adams, M. 2002 b. Shoshonitic lamprophyre dykes at the Lake George antimony deposit, New Brunswick: petrochemical characteristics and implications for gold mineralization, New Brunswick Department of Natural Resources and Energy, Minerals, Policy and Planning Division, Mineral Resource Report 2002-4, pp. 41-54.

LONGERICH, H.P. 1995. Analysis of pressed powder pellets of geological samples using wavelength-dispersive $\mathrm{x}$-ray fluorescence spectrometry. X-ray Spectrometry, 24, pp. 123-136.

LUDWIG, K.R. 1993. A computer program for processing $\mathrm{Pb}-\mathrm{U}-\mathrm{Th}$ isotope data, version 1.24, Denver. United States Geological Survey, Open File Report, 88-542, 32pp.

LUDWIG, K.R. 2000. Isoplot/Ex: A geochronological toolkit for Microsoft Excel. Bekerley Geochronology Center, Bekerley.

Lutes, G.G. 1987. Geology and geochemistry of the Pokiok Batholith, New Brunswick. New Brunswick Department of Natural Resources, Mineral Resources Branch, Report of Investigation No. 22, 74 p.

MacLellan, H.E., \& Trembath, L.T. 1991. The role of quartz crystallization in the development and preservation of igneous texture in granitic rocks: experimental evidence at 1 kbar. American Mineralogist, 76, pp. 1291-1305.

Martin, R.F., \& Bonin, B. 1976. Water and magma genesis: the association hypersolvus granite-subsolvus granite. Canadian Mineralogist, 14, pp. 228-237.

McBirney, A.R., \& Murase, T. 1984. Rheological properties of magmas. Annual Review of Earth and Planetray Science, 12, pp. 337-357.

McDonough, W.F., \& Sun, S.S. 1995. The composition of the Earth. Chemical Geology, 120, pp. 223-253.

McLeod, M.S., Johnson, S.C., \& Krogh, T.E. 2003. Archived $\mathrm{U}-\mathrm{Pb}$ (zircon) dates from southern New Brunswick. Atlantic Geology, 39, pp. 209-225.

Miller, C.F., \& Mittlefehldt, D.W. 1982. Depletion rare-earth elements in felsic magmas. Geology, 10, pp. 129-133.

MoRRISsY, C.J. 1991. Further characterization of drill core from the Lake George mine, York County, New Brunswick. New Brunswick Department of Natural Resources and Energy, Mineral Resources, Open File Report 91-8, 74 p.

Morrissy, C.J., \& Ruitenberg, A.A. 1980. Geology of the Lake George antimony deposit southern New Brunswick. Canadian Institiute of Mining and Metallurgy Bulletin, 73, pp. 79-84.

Müller, D., \& Groves, D.I. 2000. Potassic igneous rocks and associated gold-copper mineralization. Springer, New York, $252 \mathrm{p}$.

NANEy, M.T. 1983. Phase equilibria of rock-forming ferro- magnesian silicates in granitic systems. American Journal of Science, 283, pp. 993-1033.

Онмото, H., \& Goldhaber, M.B. 1997. Sulfur and carbon isotopes. In Geochemistry of hydrothermal ore deposits. Edited by H.L. Barnes, $3^{\text {rd }}$ edition, New York, John Wiley \& Sons, Inc., pp. 517-611.

PARRISH, R.R. 1987. An improved micro-capsule for zircon dissolution in U-Pb geochronology. Chemical Geology, 66, pp. 99-102.

Pearce, J.A, Harris, N.B.W., \& Tindle, A.G. 1984. Trace element discrimination diagrams for the tectonic interpretation of granitic rocks. Journal of Petrology, 25, pp. 956-983.

Procyshyn, E.L., \& Morrissy, C.J. 1990. Geology of the Lake George Mine, southern New Brunswick. In Mineral Deposits of New Brunswick and Nova Scotia. Edited by D. R. Boyle. $8^{\text {th }}$ IAGOD Symposium Field Trip Guidebook. Geological Survey of Canada, Open File 2157, pp. 58-67.

RichaRds, J.P. 2001. Discussion of "Is there a close spatial relationship between faults and plutons?". Journal of Structural Geology, 23, pp. 2025-2027.

Ruitenberg, A.A., \& FyfFe, L. R. 1982. Mineral deposits associated with granitoid intrusions and related subvolcanic stocks in New Brunswick and their relationship to Appalachian tectonic evolution. Canadian Institute of Mining and Metallurgy, Bulletin 75, no. 842, pp. 83-97.

SEAL, R.R., II, Clark, A.H., \& Morrissy, C.J. 1987. Stockwork tungsten (scheelite)-molybdenum mineralization, Lake George southwestern New Brunswick. Economic Geology, 82, pp. 1259-1282.

Seal, R.R., II, Clark, A.H., \& Morrissy, C.J. 1988. Lake George, southwestern New Brunswick: a Silurian multistage, polymetallic (Sb-W-Mo-Au-base metal) hydrothermal centre. In Recent Advances in the Geology of Granite-Related Mineral Deposits. Edited by R. P. Taylor and D. F. Strong. Canadian Institute of Mining and Metallurgy, Special Volume 39, pp. 252-264.

SHAw, H.R. 1972. Viscosities of magmatic silicate liquids: an empirical method of prediction. American Journal of Science, 272, pp. 870-893.

SHaw, H.R. 1980. The fracture mechanisms of magma transport from the mantle to the surface. In Physics of Magmatic Processes. Edited by R.B. Hargraves. Princeton University Press, pp. 201-264.

Scratch, R.B., Watson, G.P., Kerrich, R., \& Hutchinson, R.W. 1984. Fracture-controlled antimony-quartz mineralization, Lake George deposit, New Brunswick: mineralogy, geochemistry, alteration, and hydrothermal regimes. Economic Geology, 79, pp. 1159-1186.

Stacey, J.S., \& Kramers, J.D. 1975. Approximation of terrestrial lead isotope evolution by a two stage model. Earth Planetary Sciences Letters, 26, pp. 207-221.

STIRLING, J.A.R. 1979. Crystallization of a felsic dyke. Unpublished M.Sc. thesis, University of New Brunswick, Fredericton, N.B., $110 \mathrm{p}$.

WeDEPOHL, K.H. 1995. The composition of the continental 
crust. Geochimica et Cosmochimica Acta, 59, pp. 12171232.

WeINBERG, R.F. 1996. Ascent mechanism of felsic magmas: news and views. Transactions of the Royal Society of Edinburgh: Earth Sciences, 87, pp. 95-103.

Whalen, J.B. 1993. Geology, petrology, and geochemistry of Appalachian granites in New Brunswick and Gaspésie, Quebec. Geological Survey of Canada, Bulletin 463, 124 p.

Whalen, J.B., Jenner, G.A., LongstafFe, F.J., \& Hegner, E. 1996. Nature and evolution of the eastern margin of Iapetus: geochemical and isotopic constraints from Siluro-Devonian granitoid plutons in the New Brunswick Appalachians. Canadian Journal of Earth Sciences, 33, pp. 140-155.

Wohletz, K., \& Heiken, G. 1991. Volcanology and Geothermal Energy. University of California, $432 \mathrm{p}$.

Wones, D.R. 1981. Mafic silicates as indicators of intensive variables in granitic magmas. Mining Geology, 31, pp. 191-212.

YANG X.M. 2005. Petrogenesis of gold-related granitoid intrusions in southwestern New Brunswick, Canada. Unpublished Ph.D. thesis, University of New Brunswick, Fredericton, NB.

YANG, X., LentZ, D., \& CHI, G. 2002a. Petrochemistry of Lake George granodiorite stock and related gold mineralization, York County, New Brunswick. Geological Survey of Canada, CR Report 2002-D7, 10 p.

Yang, X., Lentz, D., Hall, D.C., \& Chi, G. 2002b. Petrology of the Lake George granodiorite stock, New Brunswick: implications for crystallization conditions, volatile exsolution, and W-Mo-Au-Sb mineralization. Geological Survey of Canada, CR Report 2002-E14, 12 p.

Yang, X.M., Lentz, D.R., \& McCutcheon, S.R. 2003. Petrochemical evolution of subvolcanic granitoid intrusions within the Late Devonian Mount Pleasant Caldera, southwestern New Brunswick, Canada: comparison of Au versus Sn-W-Mo-polymetallic mineralization systems. Atlantic Geology, 39, pp. 97-121.

Editorial responsibility: Sandra M. Barr

\section{APPENDIX: ANALYTICAL METHODS}

Ten drill-hole core samples from 15 to $25 \mathrm{~cm}$ in length were collected from the diamond-drill holes along the length of the QFP dyke on the Lake George mine property. These samples were taken from vertical depths between $37.5 \mathrm{~m}$ (123 ft.) to $392 \mathrm{~m}$ (1286 ft.) depending on the drillhole intersection. Core exhibiting significant weathering or alteration was avoided. The samples were crushed, then pulverized using a soft steel mill at the University of New Brunswick. Portions of each sample were sent to Actlabs for instrumental neutron activation analysis (INAA), which provided $\mathrm{As}, \mathrm{Au}, \mathrm{Ag}, \mathrm{Ba}, \mathrm{Br}, \mathrm{Ce}, \mathrm{Co}, \mathrm{Cs}, \mathrm{Cr}$, Eu, Hf, Hg, La, Lu, Mo, Nd, Ni, Rb, Sb, Sc, Se, Sm, Ta, Tb,
Th, U, W, $\mathrm{Yb}$, and $\mathrm{Zn}$. The remainder of the pulped samples were analysed for $\mathrm{Al}_{2} \mathrm{O}_{3}, \mathrm{CaO}, \mathrm{Fe}_{2} \mathrm{O}_{3}$ (total), $\mathrm{K}_{2} \mathrm{O}, \mathrm{MgO}, \mathrm{MnO}$, $\mathrm{Na}_{2} \mathrm{O}, \mathrm{P}_{2} \mathrm{O}_{5}, \mathrm{SiO}_{2}$, and $\mathrm{TiO}_{2}$ by fused disk and $\mathrm{As}, \mathrm{Ba}, \mathrm{Cl}, \mathrm{Cr}$, $\mathrm{Cu}, \mathrm{Ga}, \mathrm{Nb}, \mathrm{Ni}, \mathrm{Pb}, \mathrm{Rb}, \mathrm{Sr}, \mathrm{S}$, Th, U, V, Y, Zn, and Zr by pressed pellet X-ray fluoresence analysis at Memorial University (see Longerich 1995) (see Table 2).

The certified standard SY-4 was included as our internal standard for analytical quality control. The percent difference was calculated from the results obtained from both laboratories; where an element was analysed by both methods the result that was closer to the standard was used, choices which are indicated in Table 1 . The percent error in the trace-element analyses is generally high where the standard had low abundance of the analysed element. If the quantity of the trace elements in the standard was higher than $10 \mathrm{ppm}$, then the percent error is generally less than ten percent.

Sulphur isotope analyses were performed on bulk rock samples at the University of Ottawa using the method detailed in Yang (2005).

Ten polished thin sections were analysed optically to document petrology, with follow up using the JEOL 6400 scanning electron microscope (SEM) and backscattered electron (BSE) imaging at the Electron Microscopy Unit at the University of New Brunswick. Individual grain analysis was conducted using an energy dispersive spectrometer (EDS).

For the U-Pb ID-TIMS dating technique, a heavy mineral separate was prepared from a $10 \mathrm{~kg}$ rock sample. The sample was pulverized using a heavy-duty hydraulic rock splitter, jaw crusher and swing mill. Mineral separation involved the use of a Wilfley Table, heavy liquids (bromoform and methylene iodide) and a Frantz Isodynamic Separator. Analyses were performed at Memorial University of Newfoundland, Canada. Normal transmitted and reflected light microscopy, as well as SEM back-scattered or cathodoluminescence (CL) imagery were used to determine the zircon internal structures prior to analysis. Handpicked zircons were abraded (Krogh 1982), then washed in dilute nitric acid and ultra-pure acetone. Single grains or small populations of zircons (max. 2 grains) were then placed into $0.35 \mathrm{ml}$ Teflon vials together with $\mathrm{HF}$ and few drops of $\mathrm{HNO}_{3}$ and a mixed ${ }^{205} \mathrm{~Pb}^{-235} \mathrm{U}$ spike. These Teflon vials were then placed in a Parr Container for several days at 210 ${ }^{\circ} \mathrm{C}$ (Parrish 1987). The samples were measured on a Finnigan MAT262 mass spectrometer equipped with an ion-counting secondary electron multiplier. A detailed account of the entire analytical technique was been given by Dubé et al. (1996).

Total $\mathrm{Pb}$ blanks over the period of the analyses range from 5 to $1 \mathrm{pg}$ and a value of $5 \mathrm{pg}$ was assigned as the laboratory blank $\left({ }^{206} \mathrm{~Pb} /{ }^{204} \mathrm{~Pb}=18.97,{ }^{207} \mathrm{~Pb} /{ }^{204} \mathrm{~Pb}=15.73\right.$, and ${ }^{208} \mathrm{~Pb} /{ }^{204} \mathrm{~Pb}$ $=39.19)$. The calculation of common $\mathrm{Pb}$ was carried out by subtracting blanks and then assuming that the remaining common $\mathrm{Pb}$ has a Paleozoic composition determined from the model of Stacey and Kramers (1975). Data were reduced using PbDat (Ludwig 1993). Analytical uncertainties are listed at $2 \sigma$ and age determinations were processed using Isoplot/Ex (Ludwig 2000). 
